\title{
Mapping wetland loss and restoration potential in Flanders (Belgium): an ecosystem service perspective
}

\author{
$\underline{\text { Kris Decleer }}^{1}, \underline{\text { Jan Wouters }}^{1}, \underline{\text { Sander Jacobs }}^{1}, \underline{\text { Jan Staes }}^{2}, \underline{\text { Toon Spanhove }}^{1}$, Patrick Meire $^{2}$ and $^{\text {Rudy van Diggelen }}{ }^{2}$
}

\begin{abstract}
With the case of Flanders (northern part of Belgium) we present an integrated approach to calculate accurate losses of wetlands, potentials for restoration, and their ecosystem services supplies and illustrate how these insights can be used to evaluate and support policy making. Flanders lost about $75 \%$ of its wetland habitats in the past $50-60$ years, with currently only 68,000 ha remaining, often in a more or less degraded state. For five different wetland categories (excluding open waters) we calculated that restoration of lost wetland is still possible for an additional total area of about 147,000 ha, assuming that, with time and appropriate measures and techniques, the necessary biophysical and ecological conditions can more or less be restored or created. Wetland restoration opportunities were mapped according to an open and forested landscape scenario. Despite the fact that for 49,000 ha wetland restoration is justifiable by the actual presence of an appropriate spatial planning and/or protection status, the official Flemish nature policy only foresees 7,400 to 10,600 ha of additional wetland (open waters excluded) by 2050 . The benefits of a more ambitious wetland restoration action program are underpinned by an explorative and quantified analysis of ecosystem service supply for each of the two scenarios, showing that the strongly increased supply of several important regulating and cultural ecosystem services might outweigh the decrease of food production, especially if extensive farming on temporary wet soils remains possible. Finally, we discuss the challenges of wetland restoration policies for biodiversity conservation and climate change.
\end{abstract}

Key Words: ecosystem service valuation; wetland loss; wetland policy; wetland restoration scenarios

\section{INTRODUCTION}

It is estimated that the world lost at least $50 \%$ of its wetlands during the 20th Century (UNWWAP 2003, Davidson 2014). Some two thirds of the European wetlands have been lost in the same period (European Commission 1995), leading to a substantial decrease in the number, size, and quality of bogs, marshes, wet grasslands, and shallow lakes. Over a timespan of multiple centuries wetland loss is much higher because draining, conversion, and infilling of coastal and inland wetlands in Europe has been ongoing since at least Roman times (Russi et al. 2013). During that period wetlands were converted from uninhabitable, remote areas, with often harsh and unhealthy living conditions, into more productive, accessible, and human-friendly rural landscapes.

Exact figures of contemporary wetland loss in Europe are hard to find. For the period 1950-1985 wetland loss in six European countries was roughly estimated to lie between $55 \%$ and $67 \%$ (European Commission 2007), however without providing any supporting data or references. Based on Corine (the EEA's "coordination of information on the environment") land cover data, it was estimated that between 1990 and 2006 another 5\% $\left(1267 \mathrm{~km}^{2}\right)$ of Europe's marshes and bogs were lost (EEA 2010). On the other hand, coastal wetlands remained more or less stable and open waters had even increased by $4.4 \%\left(1581 \mathrm{~km}^{2}\right)$ in the same period (EEA 2010), the latter probably mainly in the form of artificial water bodies such as new dam and water storage constructions (Acreman 2012). The European Habitats Directive now protects 47 different wetland habitat types and 290 species (plants, invertebrates, fish, amphibians, reptiles, mammals) linked to wetlands. In 2006 however, nearly two-thirds of the species and more than three-quarters of the habitats throughout the EU member states were in unfavorable conservation status (ETC/BD 2008). Even more worrying, for the Boreal and Atlantic regions where large areas of wetlands (used to) occur, none of the habitats was in a favorable status. The successive (2007-2012) assessment indicates a further decrease (European Commission 2015).

This ongoing loss and deterioration of European wetlands contrasts sharply with their well-known values for society, recognized decades ago (e.g., Thibodeau and Ostro 1981, Batie and Shabman 1982, Farber 1987, Costanza et al. 1989, Folke 1991, Gren et al. 1994). The TEEB-review study ("The Economics of Ecosystems and Biodiversity") for water and wetlands (Russi et al. 2013) clearly mentions the major ecosystem services provided: flood protection, water supply, water purification, carbon sequestration, climate regulation, production of raw materials and food, tourism and recreation, aesthetic and cultural values. In 2012, United Nations Environment Programme (UNEP) called for urgent integration of the key role of wetlands into decision making, and the need for their future protection, restoration, and sustainable use as a vital component of the transition into a resource-efficient, sustainable world economy (http://www.unep. org/newscentre/Default.aspx? DocumentID=2697\&ArticleID=9305\&l= en). The importance of wetlands has, on various occasions, been recognized within the framework of the $\mathrm{CBD}$ (e.g., COP Decision $\mathrm{X} / 28$, UNEP/CBD/COP/DEC/X/28, 29 October 2010; COP Decision XI/23, UNEP/CBD/COP/DEC/XI/23, 5 December 2012; Message of the Executive Secretary of the Convention on Biological Diversity Braulio F. De Souza Dias of 2 February 2016, https://www.cbd.int/doc/speech/2016/sp-2016-01-28-wwd-en.pdf).

Because many benefits of wetlands are of nonmarket and public nature they are rarely represented nor defended in decisionmaking processes. Governments who want to develop an evidence-based policy on wetlands will rely heavily on the availability of scientific information. A first and essential step in this process is to make the consequences of different land-use scenarios as explicit as possible. In the present paper we follow a spatially explicit approach balancing past wetland losses with 
Table 1. Wetland typology of the study, their encompassing habitat types, and indication whether or not potentials for restoration were calculated.

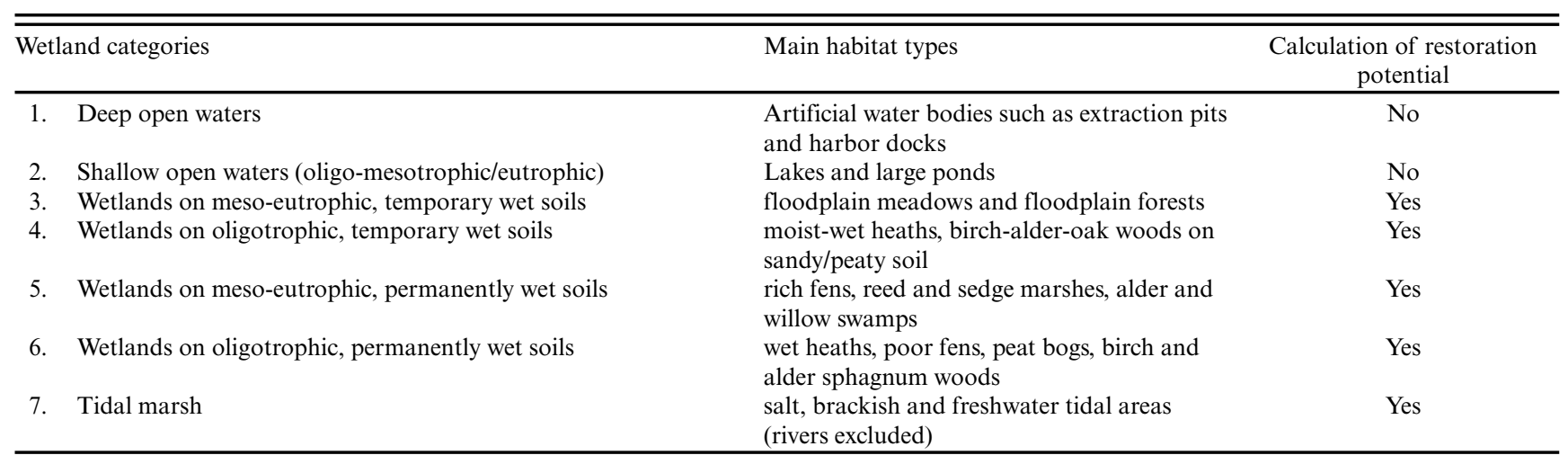

potential gains from restoration and associated ecosystem service benefits and translating this into restoration opportunities. This approach enables us to identify synergies and trade-offs between alternative land-use planning policies and restoration scenarios. We test this integrated approach in Flanders (northern part of Belgium), one of the most degraded wetland regions in Europe. We successively describe and discuss the following:

1. the loss of different wetland types since the 1950s (as an important turning period in Flemish land-use development and with detailed soil maps available from that same period) ;

2. the mapping of two realistic wetland restoration (and creation) scenarios;

3. the potential ecosystem service benefits of both scenarios;

4. the evaluation of current wetland restoration policies with a brief discussion on future challenges, as an illustration how results from our integrated approach could be used in decision making processes.

\section{METHODS}

\section{Study area}

The region of Flanders is situated in the northern half of Belgium and covers 13,522 $\mathrm{km}^{2}$. Bordering the North Sea and the Netherlands, the area is rather flat, partly reclaimed from the sea (polders), and large parts are dominated by wide river valleys and a dense network of slow-running watercourses. The highest point only reaches $156 \mathrm{~m}$ above sea level. It has a maritime climate with an annual precipitation of $800 \mathrm{~mm}$ and mild winters and summers (average of $3{ }^{\circ} \mathrm{C}$ in January and $21^{\circ} \mathrm{C}$ in July). These conditions explain the large historical density of wetlands. Currently $45 \%$ of the region is used for intensive agriculture, heavily fertilized and drained or irrigated. Another $26 \%$ of the land is urbanized (470 inhabitants $/ \mathrm{km}^{2}$ ) and $13 \%$ of the soils are sealed (De Meyer et al. 2011). This has resulted in a substantial and steady increase of the number of recorded floods since the 1970s and an average yearly economic damage of 50 million euro (VMM 2014a). Remaining wetlands cover only $5 \%$ of the region and suffer from eutrophication, pollution, and disturbed hydrological regimes. All 25 wetland habitat types protected by the Habitats Directive are in an unfavorable conservation status (Louette et al. 2013). Most peat soils were extracted in medieval times and nearly all of the 6000 ha of remaining peat soils are heavily fragmented and assumed to be in a degraded, mineralized state.

\section{Wetland classification and mapping}

In this paper wetlands are defined as temporary or permanently wet, nonmarine areas where typical wetland biodiversity is (still) more or less present. Consequently, "lost wetlands" must be understood as areas that, apart from ditches and small rivers or ponds, can no longer be considered as "wet" and lack typical wetland communities, including the temporary residing of migrating waterfowl. In our case wetland loss is not to be confused with degraded, damaged, or polluted wetlands, as is sometimes discussed in other literature (Davidson 2014).

We distinguished seven wetland categories (Table 1) based on drainage class (open water, permanently or temporary wet soil, tidal marsh) and trophic state (meso-, eu- or oligotrophic). Open waters (artificial water bodies, lakes, and large ponds) were included in the mapping and calculation of historical wetland loss, but were not considered in the restoration scenarios because their restoration/creation preconditions are less stringent.

Spatial analysis considered the following main maps:

1. the Flemish Soil Map (ALBON 2014), based on a detailed soil and drainage survey in mainly the 1950-1960s, was interpreted as a reference map for historical environmental conditions and presence of different wetland types;

2. the Biological Valuation Map (Vriens et al. 2011, INBO 2015), surveyed in the period 1998-2007, shows the actual distribution of wetlands and was used to assess shifts in drainage class and land use as opposed to the Flemish Soil Map;

3. the Flood Hazard Map of 2014 (produced for the EU Floods Directive and adapted by excluding urban areas and arable land) indicates flood plain areas where biological values, e.g., waterfowl, are still present or could be restored (VMM 2014b);

4. maps derived from the POTNAT model, which modeled potentials for the restoration or creation of 18 wetland 
Table 2. Ecosystem services considered in this study, the quantification units used for supply mapping (indicator), and the respective reference chapter of the Flanders regional ecosystem service assessment (Jacobs et al. 2014a, Stevens et al. 2015). References of individual chapters are listed in Appendix 9. For the biophysical and monetary estimates (wood production, climate regulation, food production, water quality regulation, and flood risk regulation) additional data from the ECOPLAN project was used.

\begin{tabular}{llll}
\hline \hline Code & Ecosystem Service & Mapping Indicator Unit & Reference \\
\hline C1 & Cultural Services & \% cover of valuable landscapes & Simoens et al. 2014 \\
R1 & Flood Risk Regulation & expert scored flood and land use maps & Schneiders et al. 2014 \\
R2 & Coastal Protection & m of natural coastal protection/ha & Provoost et al. 2014 \\
R3 & Water Quality Regulation & \% potential nitrogen removal & Vrebos et al. 2014a \\
R4 & Pollination & \% surface within reach of pollinators & De Bruyn 2014 \\
R5 & Air Quality Regulation & roughness index & Neirynck and Stevens 2014 \\
R6 & Climate Regulation & kg carbon stored/ha & Lettens et al. 2014 \\
R7 & Erosion Risk regulation & \% cover of soilfixing vegetation & Van der Biest et al. 2014 \\
R8 & Sound buffer & absorbing surface/ha & De Blust and Van Renterghem 2014 \\
P1 & Energy Crop Production & tonnes/ha & Van Kerckvoorde and Van Reeth 2014 \\
P2 & Wood Production & $\mathrm{m}^{3} /$ ha & Vandekerkhove et al 2014 \\
P3 & Wild Meat Production & $\mathrm{kg} / \mathrm{ha}$ & Scheppers and Casaer 2014 \\
P4 & Ground Water production & $\mathrm{m}$ infiltrated/ha & Vrebos et al 2014b \\
P5 & Food Production & $\%$ of maximal potential yield & Van Gossum et al. 2014 \\
\hline
\end{tabular}

habitat types based on local abiotic and biotic conditions (Wouters et al. 2013);

5. Additional maps on tidal marshes, historic forest cover, and current land use (De Keersmaeker et al. 2001).

For GIS analysis all maps were transformed into grid cells of 20 x $20 \mathrm{~m}$. The area of water courses was considered constant over time and excluded from the analysis to avoid large errors in the calculation of area because of this grid transformation. All currently urbanized areas were considered to be not suitable for wetland restoration. For nonurbanized areas we assumed that in the long term the environmental conditions, as they were recorded in the 1950s, can be restored with appropriate measures. Further details about maps and spatial analysis are provided in supplementary material (Appendix 1 and 2).

\section{Scenarios for potential wetland restoration}

For the calculation of the area of potential wetlands we distinguished two management scenarios: (1) an open (not forested) landscape scenario, and (2) a closed (forested) landscape scenario. To obtain realistic scenarios, the legal protection ("standstill principle") for existing forests and open habitat types with nature value were taken into account.

\section{Socioeconomic potential of wetland restoration}

We followed two approaches. First, the ecosystem service (ES) supply potential of the restoration scenarios was estimated for a broad bundle of services (see Table 2), based on the results of the Flanders Regional Ecosystem Assessment (Jacobs et al. 2014a, 2015, Stevens et al. 2015). Additionally, the socioeconomic relevance of this change in supply is demonstrated by estimating a monetary value for a selection of five services for which reliable monetary data are available from the ECOPLAN project (http:// www.ecosysteemdiensten.be/cms/, https://www.uantwerpen.be/ en/rg/ecoplan/).

The ES profile of the different wetland categories was obtained by a direct overlay of the wetland maps with ES supply maps from the Flanders regional ecosystem assessment (Stevens et al. 2015), and the consequent calculation of median supply per wetland category. Prior to the overlay, maps were normalized $(0-100)$ to allow cross-service comparison and graphing along the same unitaxis. Scenario-changes in relative provision of the entire bundle of ESs were estimated based on the surface changes of 114 landuse classes for the whole of Flanders and their averaged and normalized ES-supply per ha and per year. This derived ES supply map based on 114 land-use classes allows direct translation of land-use scenarios to ecosystem service supply impact without redefining all biophysical and socioeconomic variables in the original quantification maps. To calculate the total impact on the level of the Flanders region, first, the total supply per ES of each habitat was multiplied with the surface area of this habitat, and normalized to obtain an ES supply profile for the whole of Flanders. Second, changes in these surfaces for each scenario provided alternative profiles. Finally, the relative difference between the scenario profile and the reference (current) profile provides the impact of the scenario in terms of increases and decreases in ES supply.

Monetary estimates were performed for wood production, climate regulation (as carbon storage in soils), food production, water quality regulation, and flood risk regulation (as water quantity regulation). The quantification and valuation methods have all been developed specifically for the Flemish Region (Broekx et al. 2013a,b, VITO 2014) and adapted to spatially explicit models at high resolution (ECOPLAN-project, details in Appendix 3). This monetization only aims at demonstrating the socioeconomic relevance of the multiple benefits from wetlands. Valuation for (societal) cost-benefit analysis, would have to include many other services, cost estimates, discount rates, assumptions on constant demand per service, additional quantification of nonmarket values, etc. (Dendoncker et al. 2014, Boeraeve et al. 2015). For all five services, the two scenarios were compared to the actual land use as baseline.

To translate the forest and open landscape scenarios into the datadriven models, the following assumptions were made:

- In the forest scenario wetland restoration on current low biodiversity crop and grasslands is realized by spontaneous 
Table 3. Estimations of the historical ( \pm 1950 s), actual $( \pm 2005)$ and potential presence of seven wetland categories in Flanders (in ha). For the theoretically restorable wetlands, distinction is made between a forested and open landscape scenario. Potentials for deep and open waters were not calculated. $\dagger$

\begin{tabular}{|c|c|c|c|c|c|c|c|c|}
\hline \multirow[t]{2}{*}{ Wetland categories } & \multicolumn{2}{|c|}{$\begin{array}{c}\text { Historical } \\
(\sim 1950 \mathrm{~s})\end{array}$} & \multicolumn{2}{|c|}{$\begin{array}{l}\text { Actual } \\
(\sim 2005)\end{array}$} & \multicolumn{2}{|c|}{$\begin{array}{c}\text { Potential (open } \\
\text { landscape scenario) }\end{array}$} & \multicolumn{2}{|c|}{$\begin{array}{l}\text { Potential (forest } \\
\text { scenario) }\end{array}$} \\
\hline & ha & $\%$ & ha & $\%$ & ha & $\%$ & ha & $\%$ \\
\hline deep water & 2329 & $0.96 \%$ & 6824 & $10.05 \%$ & 6823 & $3.18 \%$ & 6823 & $3.18 \%$ \\
\hline shallow water (oligo-mesotrophic and eutrophic) & 5215 & $2.14 \%$ & 11,266 & $16.59 \%$ & 11,266 & $5.25 \%$ & 11,266 & $5.25 \%$ \\
\hline temporary wet soil (meso-eutrophic) - open & 129,059 & $52.99 \%$ & 34,676 & $51.08 \%$ & 109,457 & $51.05 \%$ & 47,687 & $22.24 \%$ \\
\hline temporary wet soil (meso-eutrophic) - forested & 14,519 & $5.96 \%$ & 6389 & $9.41 \%$ & 9227 & $4.30 \%$ & 70,997 & $33.11 \%$ \\
\hline temporary wet soil (meso-eutrophic) - total & 143,579 & $58.96 \%$ & 41,065 & $60.49 \%$ & 118,684 & $55.35 \%$ & 118,684 & $55.35 \%$ \\
\hline temporary wet soil (oligotrophic) - open & 25,231 & $10.36 \%$ & 1295 & $1.91 \%$ & 21,800 & $10.17 \%$ & 2622 & $1.22 \%$ \\
\hline temporary wet soil (oligotrophic) - forested & 7523 & $3.09 \%$ & 597 & $0.88 \%$ & 4680 & $2.18 \%$ & 23,858 & $11.13 \%$ \\
\hline temporary wet soil (oligotrophic) - total & 32,754 & $13.45 \%$ & 1892 & $2.79 \%$ & 26,480 & $12.35 \%$ & 26,480 & $12.35 \%$ \\
\hline permanently wet soil (meso-eutrophic) - open & 43,939 & $18.04 \%$ & 2576 & $3.79 \%$ & 29,582 & $13.80 \%$ & 11,856 & $5.53 \%$ \\
\hline permanently wet soil (meso-eutrophic) - forested & 7368 & $3.03 \%$ & 2802 & $4.13 \%$ & 6853 & $3.20 \%$ & 24,579 & $11.46 \%$ \\
\hline permanently wet soil (meso-eutrophic) - total & 51,307 & $21.07 \%$ & 5378 & $7.92 \%$ & 36,435 & $16.99 \%$ & 36,435 & $16.99 \%$ \\
\hline permanently wet soil (oligotrophic) - open & 4266 & $1.75 \%$ & 256 & $0.38 \%$ & 3044 & $1.42 \%$ & 950 & $0.44 \%$ \\
\hline permanently wet soil (oligotrophic) - forested & 1020 & $0.42 \%$ & 539 & $0.79 \%$ & 1594 & $0.74 \%$ & 3688 & $1.72 \%$ \\
\hline permanently wet soil (oligotrophic) - total & 5286 & $2.17 \%$ & 795 & $1.17 \%$ & 4638 & $2.16 \%$ & 4638 & $2.16 \%$ \\
\hline tidal marsh - open & 2911 & $1.20 \%$ & 566 & $0.83 \%$ & 9335 & $4.35 \%$ & 3758 & $1.75 \%$ \\
\hline tidal marsh - forested & 154 & $0.06 \%$ & 103 & $0.15 \%$ & 767 & $0.36 \%$ & 6344 & $2.96 \%$ \\
\hline tidal marsh - total & 3066 & $1.26 \%$ & 669 & $0.99 \%$ & 10,102 & $4.71 \%$ & 10,102 & $4.71 \%$ \\
\hline total wetland area & 243,535 & $100 \%$ & 67,889 & $100 \%$ & 214,428 & $100 \%$ & 214,428 & $100 \%$ \\
\hline
\end{tabular}

succession. Following the abandonment of agriculture the restored wetlands on permanently wet soils gradually become forested wetlands with alder, willow, and birch and on temporary wet soils other species such as oak and ash. This scenario assumes an active water retention where mean highest groundwater tables can be above surface. Also nutrient retention and carbon storage in belowground stocks is considered to be maximized because there is no drainage and commercial timber harvesting is absent (permanently wet soils) or reduced (temporary wet soils).

- The open landscape scenario assumes open landscapes are maintained actively through conservation and agricultural management. Current low biodiversity crop and grasslands on permanently wet soils are converted into botanically and/ or faunistically more biodiverse grassland. This implies minimal drainage to a level that still allows conservation management, e.g., mowing or grazing. Mean highest groundwater levels are close to the surface and fertilizer application is absent. In temporarily wet zones extensive agricultural management would be possible with limited maintenance fertilization.

- In both scenarios, rewetting of existing forest sites is assumed. Commercial wood production assumes conversion to native species.

\section{Evaluation of the current policy for restoration of wetland biodiversity}

An important indicator for the ambition level of any European government to restore part of the lost biodiversity are its (legally defined) conservation objectives for the implementation of the Habitats and Birds Directives. We translated the habitat types and habitats of protected species into our seven wetland categories and compared the Flemish objectives to increase wetland habitat area with the calculated "restoration opportunities" (defined as potential area for wetland restoration in the two scenarios, reduced with already existing wetland area).

\section{RESULTS}

\section{Change in wetland area over time}

In the 1950 s 244,000 ha (19\% of Flanders) could still be considered wetland (Table 3 ). Currently only 68,000 ha (5\% of Flanders) remain, implying a substantial loss of almost $75 \%$ of wetland habitats over 50-60 years' time. Thirty-seven thousand ha (15\%) has been urbanized; the rest was mainly lost to intensification of agriculture and to a lesser extent also to an increase in forest production. The proportion of wetland loss differs between categories. Moist to wet heathlands and nutrient-poor grasslands decreased by $95 \%$ ( $-24,000$ ha), with an identical rate of loss for the forested parts on these soils $(-7,000$ ha). Wet floodplain grasslands and polders decreased by $75 \%$ (-95,000 ha) and floodplain forests by $55 \%$ (-8,000 ha). Historical rich fens and 
Fig. 1. Ecosystem service profiles for different wetland-type categories in Flanders. Scores are derived as the median of normalized ecosystem service supply from the Flanders Regional Ecosystem Assessment supply maps (Jacobs et al. 2014a, 2016b, Stevens et al. 2015). For instance, in permanent wet, oligotrophic, nonforested habitats (upper left panel), the pixels of this habitat on the climate regulation supply map of Flanders (R6, normalized from 0-100) have a median score of 80\%. Legend: C1 - Cultural Services; R1 - Flood Risk Regulation; R3 - Water Quality Regulation; R4 - Pollination; R5 - Air Quality Regulation; R6 - Climate Regulation ; R7 - Erosion Risk Regulation; R8 - Sound buffer; P1 - Energy Crop Production; P2 - Wood Production; P3 - Wild Meat Production; P4 - Ground Water production; P5 - Food Production. Details on quantitative units are depicted in Table 2.
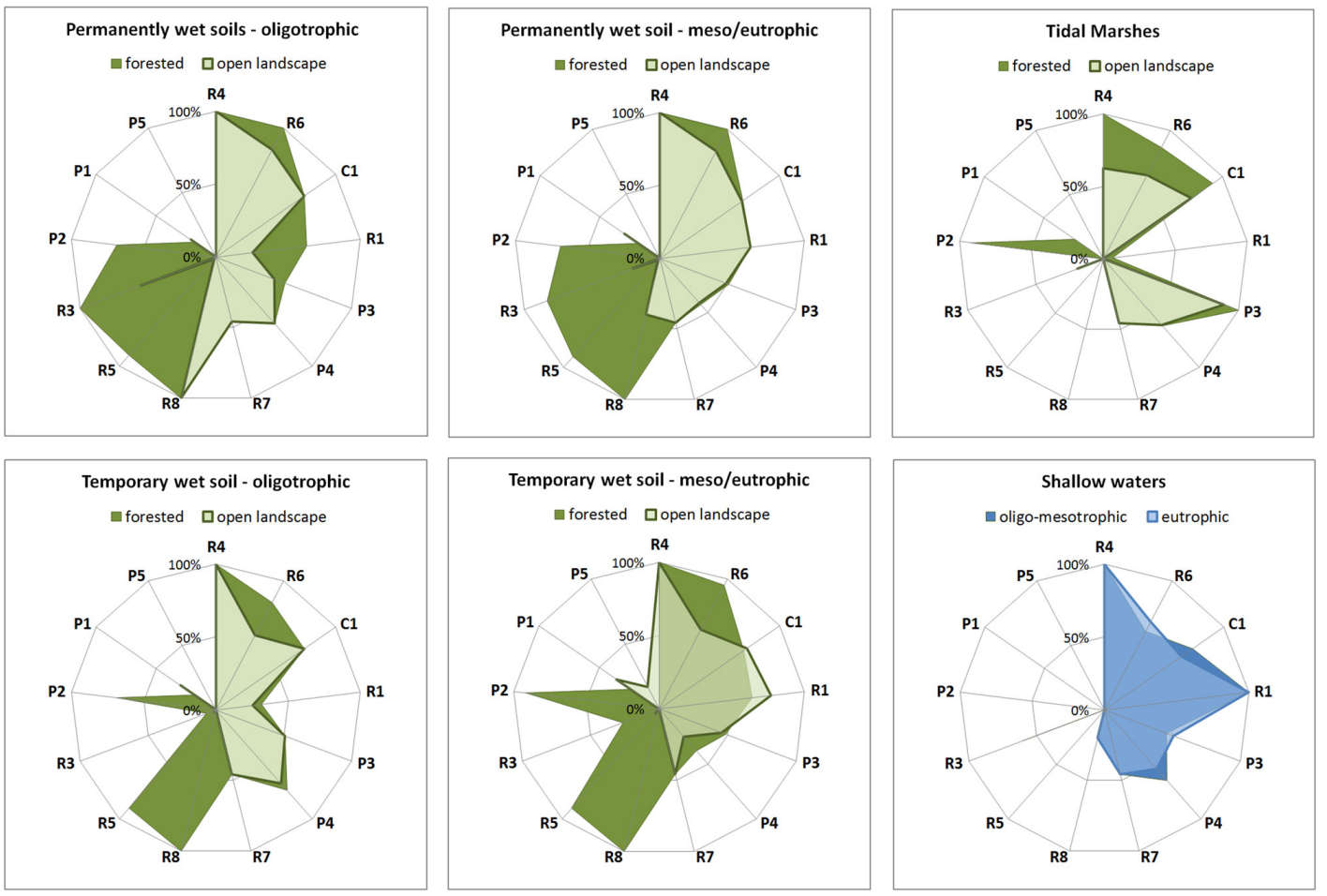

marshes decreased by $95 \%(-41,400$ ha $)$ and swamp forests by $60 \%$ (-4,500 ha). Permanently wet heathlands and open bogs showed a loss of $95 \%(-4,000 \mathrm{ha})$, while the forested version of this habitat decreased by $50 \%$ (-500 ha). Tidal marshes showed a reduction of $80 \%$ in area $(-2,400$ ha), mainly for land acquisition in the neighborhood of the port of Antwerp. In general, 20,000 ha (10\%) of open wetland habitats disappeared because of active or spontaneous afforestation, with those on permanently wet soils proportionally being most affected. In contrast with the dramatic numbers above, deep waters tripled and shallow waters doubled in surface area over those years. At present, 100\% of the deep waters and $90 \%$ of the shallow waters are eutrophic. Their trophic state could not reliably be reconstructed for the $1950 \mathrm{~s}$, but it is fair to assume that many meso- and oligotrophic waters have shifted to a eutrophic or even hypertrophic state.

\section{Potential for wetland restoration}

According to our calculations (Table 3 ) there is still a potential to restore 147,000 ha of wetland in Flanders (deep and shallow waters excluded). In the long term this could bring the total amount of wetland to 215,000 ha or $17 \%$ of the territory. With appropriate measures to restore the conditions of the $1950 \mathrm{~s}$, floodplain grasslands and forests and wet polder areas can theoretically triple in surface area to a significant 120,000 ha. Oligotrophic wetland habitats on temporary wet soils could increase 14-fold to 26,500 ha. Restoration of wetlands on permanently wet soils would lead to a 6-fold increase of open and forested wetland habitats: 36,500 ha on meso-eutrophic soils and 4500 ha on oligotrophic soils, or $72 \%$ and $88 \%$, respectively, of the original surface area of the 1950s. There is a huge potential for the restoration of tidal marsh along the river Schelde if embankments are moved inland. With many of these embankments already in place in the 1950s, this implies a 3-fold increase in area compared to the reference period and a 15 -fold increase in area compared to the current situation. The potential for restoration of shallow waters was not calculated: in principle they can be artificially created in many sites. Maps with the modeled distribution of historical, current, and potential wetland categories in Flanders are provided in Appendix 4-7.

\section{Ecosystem service supply by wetlands in Flanders}

Wetlands in Flanders provide a broad bundle of services (Fig. 1). Ecosystems on permanently wet soils provide most ecosystem services, especially forested habitats. Provision of water quality regulation, pollination, and climate regulation are the most prominent. Cultural services and flood risk regulation are also 
Table 4. Absolute losses and gains in biophysical and monetary terms for the current situation compared to a forested and open landscape wetland restoration scenario.

\begin{tabular}{|c|c|c|c|c|}
\hline \multirow[b]{2}{*}{ Ecosystem Service (ES) } & \multirow[b]{2}{*}{ Unit Value } & \multicolumn{3}{|c|}{ Scenario } \\
\hline & & Actual & Forest landscape & Open landscape \\
\hline $\begin{array}{l}\text { Water Quantity Regulation: } \\
\text { Water Quantity Regulation }\left(\mathrm{km}^{3} / \mathrm{yr}\right) \\
\text { Change in Water Quantity regulation }\left(\mathrm{km}^{3} / \mathrm{yr}\right) \\
\text { - Low estimate water Quantity Regulation (mio } € / \mathrm{yr}) \\
\text { - Mean estimate water Quantity Regulation (mio } € / \mathrm{yr}) \\
\text { - High estimate water Quantity Regulation (mio } € / \mathrm{yr})\end{array}$ & $\begin{array}{l}€ 0.075 / \mathrm{m}^{3} \\
€ 0.1375 / \mathrm{m}^{3} \\
€ 0.2 / \mathrm{m}^{3}\end{array}$ & $\begin{array}{l}1.15 \\
0 \text { (ref) }\end{array}$ & $\begin{array}{c}1.24 \\
0.09(7.6 \%) \\
6.5 \\
12.0 \\
17.4\end{array}$ & $\begin{array}{c}1.20 \\
0.06(4.8 \%) \\
4.2 \\
7.6 \\
11.1\end{array}$ \\
\hline $\begin{array}{l}\text { Water Quality Regulation: } \\
\text { Total Nitrate leaching (tonne N-NO3/yr) } \\
\text { Avoided Nitrate leaching (tonne N-NO3/yr) } \\
\text { Denitrification (tonne N-NO3/yr) } \\
\text { Change in denitrification (tonne N-NO3/yr) } \\
\text { Total immission to surface water (tonne N-NO3/yr) } \\
\text { Total avoided immission to surface water (tonne N-NO3/yr) } \\
\text { - Low estimate avoided N-immission to surface water (mio } € / y r) \\
\text { - Mean estimate avoided N-immission to surface water (mio } € / \mathrm{yr} \text { ) } \\
\text { - High estimate avoided N-immission to surface water (mio } € / \mathrm{yr} \text { ) }\end{array}$ & $\begin{array}{l} \\
€ 5 / \mathrm{kg} \\
€ 39.5 / \mathrm{kg} \\
€ 74 / \mathrm{kg}\end{array}$ & $\begin{array}{l}33,764 \\
0 \text { (ref) } \\
19,268 \\
0 \text { (ref) } \\
14,496 \\
0 \text { (ref) }\end{array}$ & $\begin{array}{c}28,375 \\
5,389(-16 \%) \\
16,955 \\
-2,314(-12 \%) \\
11,421 \\
3,075(-21.2 \%) \\
15.4 \\
121.5 \\
227.6\end{array}$ & $\begin{array}{c}29,933 \\
3,831(-11.3 \%) \\
18,462 \\
-806(-4.2 \%) \\
11,471 \\
3,024(-20.9 \%) \\
15.1 \\
119.5 \\
223.8\end{array}$ \\
\hline $\begin{array}{l}\text { Climate Regulation: } \\
\text { Climate Regulation (Soil organic Carbon - tonne C) } \\
\text { Change in Soil organic Carbon - tonne C) } \\
\text { - Low estimate climate Regulation (mio } € \text { ) - mean annual next } 50 \text { years } \\
\text { - Mean estimate climate Regulation (mio } € \text { ) - mean annual next } 50 \text { years } \\
\text { - High estimate climate Regulation (mio } € \text { ) - mean annual next } 50 \text { years }\end{array}$ & $\begin{array}{l}€ 20 / \text { ton } \\
€ 120 / \text { ton } \\
€ 220 / \text { ton }\end{array}$ & $\begin{array}{c}141,229,133 \\
0 \text { (ref) }\end{array}$ & $\begin{array}{c}146,357,439 \\
5,128,306(3.6 \%) \\
2.1 \\
12.3 \\
22.6\end{array}$ & $\begin{array}{c}142,658,680 \\
1,429,548(1 \%) \\
0.6 \\
3.4 \\
6.3\end{array}$ \\
\hline $\begin{array}{l}\text { Agricultural production: } \\
\text { Agricultural production (mio } € / y r) \\
\text { • Change in agricultural production (mio } € / y r \text { ) }\end{array}$ & Direct & $\begin{array}{l}1,300.9 \\
0 \text { (ref) }\end{array}$ & $\begin{array}{c}1,115.9 \\
-185(-14.2 \%)\end{array}$ & $\begin{array}{c}1,165.0 \\
-135.9(-10.4 \%)\end{array}$ \\
\hline $\begin{array}{l}\text { Timber production: } \\
\text { Timber production (mio } € / y r) \\
\text { - Change in timber production (mio } € / y r) \\
\text { TOTAL } \\
\text { - Low estimate change in ES-delivery (mio } € / y r) \\
\text { - Mean estimate change in ES-delivery (mio } € / y r) \\
\text {-High estimate change in ES-delivery (mio } € / y r)\end{array}$ & Direct & $\begin{array}{c}12.5 \\
0 \text { (ref) }\end{array}$ & $\begin{array}{c}10.0 \\
-1.29(-10.3 \%) \\
-162.3 \\
-40.6 \\
81.2\end{array}$ & $\begin{array}{c}10.0 \\
-1.29(-10.3 \%) \\
-117.3 \\
-6.7 \\
104.0\end{array}$ \\
\hline
\end{tabular}

important, as are air quality regulation, sound buffer, and wood production in forested permanently wet habitats. Systems on temporary wet soils have a very similar profile, but perform poorer on water quality regulation. The meso- and eutrophic habitats include seminatural grasslands that can be combined with food production (haymaking, grazing). Tidal marshes differ from the former wetlands by a high cultural value and hunting potential, but deliver a lower supply of water and air quality regulation and of sound buffer. Shallow waters provide a remarkably high supply of flood risk regulation but lower supplies of water and air quality and sound buffer.

The different restoration scenarios have a significant impact on total ecosystem services supply (Fig. 2). Both the forested and the open landscape scenario lead to a decrease in food production $(-16 \%$ to $-19 \%)$, an increase in both flood risk regulation and climate regulation ( $5 \%$ to $10 \%)$, and a strong increase in water quality regulation $(31 \%$ to $46 \%)$. The forested scenario leads to an additional increase in sound buffer and wood production ( $9 \%$ ), while these services slightly decrease in the open landscape scenario (respectively, $-9 \%$ and $-2.5 \%$ ). Slight decreases occur also in the supply of coastal protection, air quality regulation, and production of energy crops.

\section{Monetary valuation of selected ES}

Land-use choices involve a broad range of values, including economic, social, and ecological values. Economic values, especially market values, have the advantage of direct and tangible valuation. Using various pricing techniques, a surrogate economic value can be obtained for several services. Although the economic nonsense of such a pricing is understood, there is sense in that it conveys the order of magnitude of socioeconomic importance these services might well represent, thus demonstrating the need to capture their broader values in decision making. Absolute losses and gains in wood production, climate regulation, food production, water quality regulation, and flood risk regulation under the restoration scenarios are shown in Table 4. Agricultural production losses for the forested landscape scenario amount up to $€ 185$ million per year, which is $14 \%$ of the total agricultural production compared with the current situation. If extensive agriculture is allowed on the temporary wet zones, this impact would be reduced with $€ 50$ million. Note that the real economic 
balance could look very different when taking into account changes in subsidies that would follow from a decrease in agricultural surface.

Fig. 2. Impact of two different wetland restoration/creation scenarios for the Flanders region. Scores are derived as the difference of total ecosystem service supply between scenarios and the current situation (driven by surface area distributions). Legend: C1 - Cultural Services; R1 - Flood Risk Regulation; R2 - Coastal Protection; R3 - Water Quality Regulation; R4 Pollination; R5 - Air Quality Regulation; R6 - Climate Regulation ; R7 - Erosion Risk Regulation; R8 - Sound buffer; P1 - Energy Crop Production; P2 - Wood Production; P3 - Wild Meat Production; P4 - Ground Water production; P5 - Food Production.

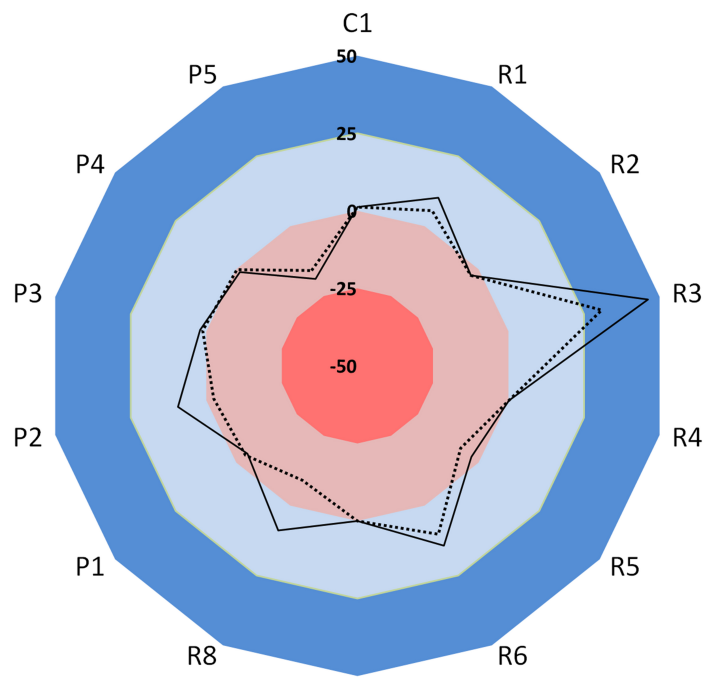

R7

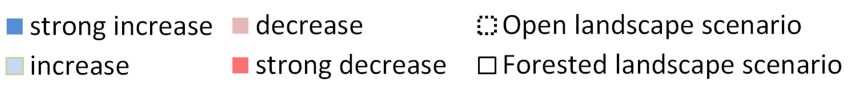

Benefits for water quality regulation (total nitrate release to surface water) are comparable for both scenarios, but depend on different aspects. While nitrate leaching is reduced most in the forested scenario, denitrification decreases significantly. In the open landscape scenario, nitrate leaching decreases less dramatically $(11.3 \%$ instead of $16 \%$ for forested), but denitrification is relatively more performant because the decrease is only $4.2 \%$ (instead of $12 \%$ for forested). The monetary benefit ranges from $€ 15$ to $€ 225$ million per year. The high estimate ( $€ 74 /$ $\mathrm{kg} \mathrm{N}-\mathrm{NO} 3$ ) is based on shadow prices of effectively implemented policy measures for nitrate in surface water (marginal cost method). Implementing a large scale restoration scenario that decreases nitrate release up to $20 \%$ would make a range of current technical measures dispensable. For correct valuation one should be able to derive a mean value for the dispensable measures. On the other hand, most water bodies do not meet the water quality standards despite the current measures.

Carbon sequestration in soils is relatively insensitive compared to the total stock in the Flemish Region, but highest under the forested scenario. The nature conservation management and agricultural management imply harvest of aboveground biomass, which results in less input to the soil compartment. This, however, does not mean that local changes cannot be important. Especially for the permanently wet ecosystems, active peat formation could be restored. Unfortunately, the quantification methods for soil organic carbon do not incorporate carbon stocks from potential peat formation.

Water quantity regulation is an ecosystem service that is likely to become more important in the next decades. Rewetting former wetland ecosystems allows increasing water retention by $7.6 \%$ under the forested scenario and by $4.8 \%$ under the open landscape scenario. This volume of additionally retained water compares to a river with a steady flow of 2.8 and $1.8 \mathrm{~m}^{3} / \mathrm{s}$, respectively. Whether the retained water could all be used for consumption can be disputed, but on the other hand this would be a service that is of strategic and crucial importance in terms of climate adaptation.

\section{Evaluation of the current policy for wetland restoration}

Comparing the restoration opportunity (potential area for wetland restoration in the two scenarios, reduced with already existing wetland area) and the objectives for wetland expansion in the Flemish Natura 2000 policy (Table 5), a significant discrepancy between the two figures appears. Present policy foresees a total wetland expansion of $8900-13,000$ ha (or $7400-10,600$ ha with open waters excluded) in 2050, including 1800-3000 ha forested wetland and 2500 ha tidal marsh. All figures are much lower than what could be reached with a more ambitious policy. The ambitions for oligotrophic and mesoeutrophic wetlands on temporary wet soils and meso-eutrophic wetlands on permanently wet soils appear to be especially modest with an increase of only $1-8 \%$ of the restoration opportunity. With a projected increase of $19-26 \%$ of the potential restorable surface, ambition levels are significantly higher for tidal marsh and wetlands on oligotrophic permanently wet soils.

\section{DISCUSSION}

Area estimations for wetland loss and restoration potential

Reliable estimations for (sub)national wetland loss, subdivided into different wetland subtypes and for an identical time period are very rare in literature (see Davidson 2014). The combination with an accurate and spatially explicit analysis of the wetlands that can potentially still be restored makes our study rather unique. Obviously, possible errors in area estimations and their mapping largely depend on the accuracy and scale of the map layers that are available for GIS analysis (Joao 1998). In the case of Flanders we were fortunate with the availability of detailed maps on a scale of 1:25,000 describing the soil conditions in the 1950 s and the recent distribution of 180 habitat types, including 40 types of wetland habitat. Such accurate maps may not be available in other regions of the world and this poses a challenge to the exact replication of our methods (see also Clare and Creed 2014). Another error source may be the use of discrete values derived from the basic map layers to define the different classes of abiotic and biotic conditions. Within the limitations of the used basic data we believe our approach provides the best possible proxy for estimating wetland loss and the present potential for wetland restoration in Flanders. However, the maps that were generated (see Appendix 4-7 in Supplementary materials) should 
Table 5. Ambition level for the expansion of wetland habitats within the Flemish Natura 2000 policy framework in perspective with the available restoration opportunities (defined as potential area for wetland restoration in the two scenarios, reduced with already existing wetland area). ${ }^{\dagger}$ All increase of alluvial forests (habitat type 91E0) was assigned to meso-eutrophic wetlands on temporary wet soil. "No distinction could be made between forested and nonforested tidal marsh.

\begin{tabular}{|c|c|c|c|}
\hline \multirow[t]{2}{*}{ Wetland categories } & \multirow{2}{*}{$\begin{array}{c}\text { Min-max } \\
\text { expansion target } \\
\text { Natura2000 (ha) }\end{array}$} & \multicolumn{2}{|c|}{$\begin{array}{l}\text { Proportion of the restoration } \\
\text { opportunity in: }\end{array}$} \\
\hline & & $\begin{array}{l}\text { Open landscape } \\
\text { scenario }\end{array}$ & $\begin{array}{c}\text { Forest landscape } \\
\text { scenario }\end{array}$ \\
\hline deep water & 0 & - & - \\
\hline shallow water (oligo-mesotrophic and eutrophic) & $1485-2366$ & ? & ? \\
\hline temporary wet soil (meso-eutrophic) - open & $1690-3275$ & $2-4 \%$ & $13-25 \%$ \\
\hline temporary wet soil (meso-eutrophic) - forested & $1800-3000$ & $63-106 \%$ & $3-5 \%$ \\
\hline temporary wet soil (meso-eutrophic) - total & $3490-6275$ & \multicolumn{2}{|c|}{$4-8 \%$} \\
\hline $\begin{array}{l}\text { temporary wet soil (oligotrophic) - open } \\
\text { temporary wet soil (oligotrophic) - forested }\end{array}$ & 128 & $1 \%$ & $10 \%$ \\
\hline temporary wet soil (oligotrophic) - total & 128 & \multicolumn{2}{|c|}{$1 \%$} \\
\hline $\begin{array}{l}\text { permanently wet soil (meso-eutrophic) - open } \\
\text { permanently wet soil (meso-eutrophic) - forested }\end{array}$ & $571-775$ & $2-3 \%$ & $6-9 \%$ \\
\hline permanently wet soil (meso-eutrophic) - total & $571-775$ & \multicolumn{2}{|c|}{$2-3 \%$} \\
\hline $\begin{array}{l}\text { permanently wet soil (oligotrophic) - open } \\
\text { permanently wet soil (oligotrophic) - forested }\end{array}$ & $736-966$ & $26-35 \%$ & $106-139 \%$ \\
\hline permanently wet soil (oligotrophic) - total & $736-966$ & \multirow{2}{*}{\multicolumn{2}{|c|}{$19-25 \%$}} \\
\hline $\begin{array}{l}\text { tidal marsh - open } \\
\text { tidal marsh - forested }\end{array}$ & $2481-2491$ & & \\
\hline tidal marsh - total & $2481-2491$ & \multicolumn{2}{|c|}{$26 \%$} \\
\hline Total wetland area & $8892-13,002$ & \multicolumn{2}{|c|}{$6-9 \%$} \\
\hline Total wetland area (excluding open waters) & $7406-10,636$ & \multicolumn{2}{|c|}{$5-7 \%$} \\
\hline
\end{tabular}

be interpreted with caution when zooming in on the individual site level. The transformation in to grid cells of $20 \times 20 \mathrm{~m}$, in combination with possible errors in the used basic map layers, may inevitably generate inaccuracies when maps are scaled down.

Concerning application of this approach in other areas, one should be aware of the impact of accuracy on the final area estimates, as was also observed by Davidson (2014). Especially in areas with low data availability, applying a min-max fork estimate could provide confident and transparent estimates.

\section{Ecosystem service supply of wetland restoration}

Estimations of ecosystem service (ES) supply per wetland category as well as the impact estimation of the scenarios on total ES supply should be handled with caution. Here, we want to point out three caveats for ES supply estimates, which apply for any case study engaging in ES quantification. First, the data used for this exercise are the best available data on ES supply at this moment. These indicators are often combinations of several data layers and combined models involving a number of reasonable (and checked) assumptions. Indicators and maps should therefore be interpreted alongside their confidence and used within the boundaries of their specific purpose. Although the indicators used in this study robustly support our conclusions, they cannot be applied to answer just any question, especially not questions that require much higher accuracy and confidence, e.g., accounting, trend analysis, development of payment schemes, etc. (see also Jacobs et al., in press). Second, the maps are made and reviewed for the regional scale. Zooming in to local levels will bring to light biases caused by local physical, ecological, or social conditions that are not captured by the models. This has little repercussions for regional-scale analyses, but it is clear that the local ES supply of wetland types will differ strongly from one location to another. Third, and following from this local scale, there might be ecosystem services relevant on the Flanders scale that are not important at all at some locations (because either supply or demand is lacking). In fact, there might be important services missing from this analysis when scaling down to the implementation level, while the basic valuation at this level does not include a differential societal importance of the services. Conclusions drawn on this exercise are strictly general and may not be used to guide a local planning process.

Our monetary estimations indicate that benefits derived from the regulating services (water quantity regulation, water quantity regulation and carbon storage in soils) range from 20 to $€ 268$ million/yr. The decrease in production services (agriculture and timber production) ranges from 137 to $€ 186$ million/yr. Much can be debated about the quantification and valuation methods, including the validity of the scenario. Nevertheless these estimates demonstrate that for at least three services, substantial benefits could be obtained. A more sophisticated scenario would probably allow decreasing the impact on agricultural production and timber production, while maintaining these regulating services. Moreover, including health benefits, tourism, and recreation could tip the balance to positive numbers (e.g., Broekx et al. $2013 b$ ). Also the current mean cost of $€ 50$ million/yr to compensate for economic damage due to flood hazards (VMM 2014a) needs to be taken into account.

Despite these caveats, this analysis clearly shows the overall importance of specific wetland habitats for supply of mainly 
regulating and cultural services on the scale of the entire region. Restoring or creating wetland habitat in Flanders can result in a strongly increased supply of several important services, and in a decrease of food production. Basic economic valuation demonstrates the high societal importance of these services. Without being conclusive, this simple valuation opens a rational debate on whether the benefits and costs involved in food production might be outweighed by the broader benefits supplied by restored areas.

Our results broadly concur with earlier valuation studies (e.g., Thibodeau and Ostro 1981, Batie and Shabman 1982, Farber 1987, Costanza et al. 1989, Folke 1991, Gren et al. 1994, Russi et al. 2013) but especially highlight that valuation exercises should be broadened to include more than monetizeable benefits. First, not all ES are increasing, and societal trade-offs have to be made between benefits and losses of Flemish wetlands. Second, benefits and losses for different users should be disentangled to account for the governance issues involved in actual realization of a certain scenario. Third, a broader value typology to integrate intrinsic values, instrumental values, and relational values should be applied to go beyond an eye-opening study toward actual decision support (Jacobs et al. 2016a).

Projected losses in food production also consider the current production model, which involves substantial financial support from public budgets, as well as issues concerning food waste and caloric efficiency of meat production. Even a slightly different production model might easily compensate projected losses in wetland areas, or provide ways of farming that can be combined with the multiple services provided in these landscapes (Jacobs et al. 2014b, Van Gossum et al. 2014). Rather than retreating to the typical historical struggle for monofunctional land-service allocation and grinding on trade-offs between services and stakeholder groups, the many existing synergies on a practical and local level could offer concrete solutions for a multifunctional, biodiversity-rich wetland use. Such an approach could evoke a more transparent and rational debate on restoration of natural habitats in intensively used areas and might be more effective in obtaining biodiversity goals.

\section{Further challenges in future wetland restoration policies for biodiversity and climate change adaptation}

\section{Past and current policy context}

To understand the current state of ecosystems in any country or region and develop new policies, insights into past and current policies are essential. With almost $75 \%$ of its wetlands lost since the 1950s, Flanders ranks highest amongst the European regions (see data in European Commission 2007). The high population density and inappropriate spatial planning and urbanization policy were important drivers, as well as the lack of coordination of water management, which is traditionally very complex with many actors on different government and administrative levels. The European Water Framework Directive (2000), the Floods Directive (2007), and increasing socioeconomic costs of flood events in urbanized areas (VMM 2014a) were important turning points in the mind setting of the Flemish water policy makers. Nowadays some of the most prestigious nature restoration projects in Flanders go hand in hand with flood protection, e.g., for the large rivers Schelde, Grensmaas, and IJzer). The once common practice of widening and straightening of rivers and urbanization of flood-prone areas has virtually stopped. A more detailed overview on Flanders-specific water management practice can be found in Appendix 8.

\section{Wetland restoration and biodiversity conservation}

Our integrated and spatially explicit approach delivers data that can be useful in the societal debate on more and better wetland restoration and is helpful to develop guidance for future decision making. In the case of Flanders we found that $35 \%$ of the remaining wetlands have no spatial planning or protection status, while 49,000 ha $(33 \%)$ of potential wetlands lack investments for restoration despite their appropriate status (see Appendix 8). As was demonstrated in many other countries (e.g., Birol et al. 2009, Buijs 2009, Scholte et al. 2016) flood protection is more widely accepted as a motivation for wetland restoration than biodiversity conservation. In the Flemish floodplains this is demonstrated by the still dominant, more or less intensive agricultural use with fertilization and active drainage of wet grasslands. Outside the floodplains, restoration projects of nutrient-poor wet grasslands and heaths on temporary or permanently wet soils remain rare and small in scale. They are mainly restricted to nature reserves in the upstream and interfluvial areas. Conflicts with the surrounding land use in terms of water levels and water quality often hamper these projects. It is the public perception that such wetlands would not contribute to flood prevention and therefore they stay beyond the reach of the (traditionally much bigger) budgets of water management administrations. In general, the lack of interest in the restoration of wetland biodiversity is also reflected in the rather low ambition level for expansion of Natura 2000 wetland habitat types and habitats for Natura 2000 wetland species, particularly those of open landscapes.

For wetland restoration in general, and for the Flanders case specifically, we conclude that more awareness raising beyond direct biodiversity values will be essential to implement a more effective long-term restoration policy for the different types of biodiversityrich wetlands. Fostering public support is not only essential, different stakeholder groups will need different kinds of information and opportunities for participation (see also Johansson and Henningsson 2011, Tolvanen et al. 2013, Aggestam 2014, Scholte et al. 2016). Studies like ours are essential to identify priority areas for restoration and create a more robust ecological network of wetlands (see also Gibbs 2000, Vos et al. 2010).

\section{Wetland restoration and climate change adaptation}

According to the most plausible scenarios described in the report of the Flanders Environment Agency (Brouwers et al. 2015) the mean temperature in Flanders may rise by up to $7.2 \%$ by 2100 , which will lead to more extreme hot days and heat stress. Summers will get drier with more concentrated heavy rain events. Precipitation will be higher during winters. The sea level may rise up to $1 \mathrm{~m}$. Combined with the predicted increase in population size and further urbanization of open space, the flood risk will further increase. Flood plain areas will hence become less valuable for agriculture and inhabitation, which is potentially facilitating their transition to (semi)natural wetlands.

Apart from reducing economic damage caused by floods (see e.g., Bullock and Acreman 2003, Acreman 2012, Acreman and Holden 2013, Walters and Babbar-Sebens 2016), both natural and artificial wetlands could produce additional adaptation services as water buffer areas to ensure sufficient water supply for the production 
of food crops in hot and dry periods (e.g., Chester and Robson 2013, Downard and Endter-Wada 2013). Artificial wetlands in cities and urban areas will become more important to reduce heat island effects and to buffer heavy rain (e.g., Persson et al. 1999, Sun et al. 2012). More wetlands will also help to remove increased nutrient runoff from cultivated catchments in regions with increased rainfall or more intensive agriculture (e.g., Gilliam 1994, Gren 1995, Woltemade 2000, Verhoeven et al. 2006, Thiere et al. 2009, Jeppesen et al. 2011, Hefting et al. 2013, Ockenden et al. 2014). To avoid depletion of ground water acquifers the creation of more temporary and permanent wetlands can increase the infiltration rate of rain water (e.g., Winter 1999). On the other hand it is possible that suitable areas for wetland restoration or even existing wetlands get lost or suffer from increased pressures in regions with increased droughts, with agricultural expansion as a possible secondary effect (e.g., Hartig et al. 1997). In general, climate change is expected to increase demand for wetland types of eutrophic, temporary wet and tidal soils (e.g. Nicholls 2004, Temmerman et al. 2013). The combination of increased evapotranspiration and more extreme weather events will probably challenge the restoration of specific wetland types that depend on more or less stable, high water levels, especially those of oligo-mesotrophic conditions (e.g., Cusell et al. 2013). Of course, restoration success will also depend on how the local geographical location is impacted by climate change (Čížková et al. 2013).

All in all, the urgency of climate change and the obvious role wetlands can play to increase resilience in multifunctional landscapes, provide arguments for their further protection and restoration. The application of accurate maps and ecosystem service assessments like this study are needed to underpin these arguments scientifically and help them to get implemented into spatial planning.

\section{CONCLUSION}

We show that despite dramatic historic wetland loss and the unfavorable status of remaining wetlands, Flanders still has a large biophysical and ecological potential for wetland restoration with the proper spatial planning or protection status already in place to justify more action in the field. Based on the best available data, we demonstrated that restoring or creating wetland habitat will result in a strongly increased supply of several important regulating and cultural ecosystem services, and in a slight decrease of food production. Benefits supplied by restored or created wetlands and avoided costs of economic damage due to flood hazards might outweigh the costs involved and the loss in food production. Different policies, specific designs and local implementation examples could offer opportunities for multifunctional use, even with producing services, of restored wetlands. An exhaustive area-wide approach, supported by innovative GIS modeling and ecosystem service valuation techniques, provide a robust tool for assisting evidence-based policy decision making that could be applied for other ecosystem types or areas.

Responses to this article can be read online at: http://www.ecologyandsociety.org/issues/responses. $\mathrm{php} / 8964$

\section{Acknowledgments:}

We would like to sincerely thank Carine Wils for her help with the GIS mapping and analyses, and the reviewers and editors of Ecology and Society and Dries Bonte for their valuable comments. SJ thanks the EU-FP7 OpenNESS project and the IWT ECOPLAN project for financial support and both project teams for inspiring moments and discussions.

\section{LITERATURE CITED}

Acreman, M. C. 2012. Wetlands and water storage: current and future trends and issues. Ramsar Convention Secretariat, Gland, Switzerland.

Acreman, M., and J. Holden. 2013. How wetlands affect floods. Wetlands 33:773-786. http://dx.doi.org/10.1007/s13157-013-0473-2

Aggestam, F. 2014. Wetland restoration and the involvement of stakeholders: an analysis based on value-perspectives. Landscape Research 39:680-697. http://dx.doi.org/10.1080/01426397.2013.819076

ALBON. 2014. Bodemkaart: bodemtypes, substraten, fasen en varianten van het moedermateriaal en de profielontwikkeling. ALBON, Brussels, Belgium. [online] URL: http://www.geopunt. be/catalogus/datasetfolder/5c129f2d-4498-4bc3-8860-01cb2d513f8f

Batie, S. S., and L. A. Shabman. 1982. Estimating the economic value of wetlands: principles, methods, and limitations. Coastal Zone Management Journal 10:255-278. http://dx.doi. org/10.1080/08920758209361920

Birol, E., N. Hanley, P. Koundouri, and Y. Kountouris. 2009. Optimal management of wetlands: quantifying trade-offs between flood risks, recreation, and biodiversity conservation. Water Resources Research 45(11). http://dx.doi.org/10.1029/2008WR006955

Boeraeve, F., N. Dendoncker, S. Jacobs, E. Gómez-Baggethun, and M. Dufrêne. 2015. How (not) to perform ecosystem service valuations: pricing gorillas in the mist. Biodiversity and Conservation 24:187-197. http://dx.doi.org/10.1007/s10531-014-0829-9

Broekx, S., L. De Nocker, I. Liekens, L. Poelmans, J. Staes, K. Van der Biest, P. Meire, and K. Verheyen. 2013a. Estimate of the benefits delivered by the Flemish Natura 2000 network. 2013/RMA/ $\mathrm{R} / 87$. University of Antwerp and University of Ghent, The Netherlands.

Broekx, S., I. Liekens, W. Peelaerts, L. De Nocker, D. Landuyt, J. Staes, P. Meire, M. Schaafsma, W. Van Reeth, O. Van den Kerckhove, and T. Cerulus. 2013b. A web application to support the quantification and valuation of ecosystem services. Environmental Impact Assessment Review 40:65-74. http://dx.doi. org/10.1016/j.eiar.2013.01.003

Brouwers, J., B. Peeters, M. Van Steertegem, N. van Lipzig, H. Wouters, J. Beullens, M. Demuzere, P. Willems, K. De Ridder, B. Maiheu, R. De Troch, P. Termonia, T. Vansteenkiste, M. Craninx, S. W. Maeten, W. Defloor, and K. Cauwenberghs. 2015. MIRA Climate report 2015, about observed and future climate changes in Flanders and Belgium. Flanders Environment Agency in collaboration with KU Leuven, VITO and RMI, Aalst, Belgium. 
Buijs, A. E. 2009. Public support for river restoration. A mixedmethod study into local residents' support for and framing of river management and ecological restoration in the Dutch floodplains. Journal of Environmental Management 90:2680-2689. http://dx.doi.org/10.1016/j.jenvman.2009.02.006

Bullock, A., and M. Acreman. 2003. The role of wetlands in the hydrological cycle. Hydrology and Earth System Sciences 7:358-389 http://dx.doi.org/10.5194/hess-7-358-2003

Chester, E. T., and B. J. Robson. 2013. Anthropogenic refuges for freshwater biodiversity: their ecological characteristics and management. Biological Conservation 166:64-75. http://dx.doi. org/10.1016/j.biocon.2013.06.016

Čížková, H., J. Květ, F.A. Comín, R. Laiho, J. Pokorný, and D. Pithart. 2013. Actual state of European wetlands and their possible future in the context of global climate change. Aquatic Sciences 75:3-26. http://dx.doi.org/10.1007/s00027-011-0233-4

Clare, S., and I. F. Creed. 2014. Tracking wetland loss to improve evidence-based wetland policy learning and decision making. Wetlands Ecology and Management 22:235-245. http://dx.doi. org/10.1007/s11273-013-9326-2

Costanza, R., S. C. Farber, and J. Maxwell. 1989. Valuation and management of wetland ecosystems. Ecological Economics 1:335-361 http://dx.doi.org/10.1016/0921-8009(89)90014-1

Cusell, C., L. P. M. Lamers, G. van Wirdum, and A. Kooijman. 2013. Impacts of water level fluctuation on mesotrophic rich fens: acidification vs. eutrophication. Journal of Applied Ecology 50:998-1009. http://dx.doi.org/10.1111/1365-2664.12096

Davidson, N. C. 2014. How much wetland has the world lost? Long-term and recent trends in global wetland area. Marine and Freshwater Research 65:934-941. http://dx.doi.org/10.1071/ $\underline{\mathrm{MF} 14173}$

De Keersmaeker, L., N. Rogiers, R. Lauriks, and B. De Vos. 2001. Ecosysteemvisie Bos Vlaanderen, Ruimtelijke uitwerking van de natuurlijke bostypes op basis van bodemgroeperingseenheden en historische boskaarten. Eindverslag van project VLINA C97/06, studie uitgevoerd binnen het kader van het Vlaams Impulsprogramma Natuurontwikkeling. The Institute for Forestry and Game Management, Brussels, Belgium.

De Meyer, A., D. Tirry, H. Gulinck, and J. Van Orshoven. 2011. Actualisatie MIRA Achtergronddocument Bodem. Thema Bodemafdichting. Eindrapport. Studie uitgevoerd in opdracht van de Vlaamse Milieumaatschappij. MIRA, SADL \& Departement Aard- en Omgevingswetenschappen, K.U. Leuven, Belgium.

Dendoncker, N., H. Keune, S. Jacobs, and E. Gomez-Baggethun. 2014. Inclusive e cosystem service valuation. Pages 3-12 in S. Jacobs, N. Dendoncker, and H. Keune, editors. Ecosystem services: global issues, local practices. Elsevier, New York, New York, USA. http:// dx.doi.org/10.1016/b978-0-12-419964-4.00001-9

Downard, R., and J. Endter-Wada. 2013. Keeping wetlands wet in the western United States: adaptations to drought in agriculture-dominated human-natural systems. Journal of Environmental Management 131:394-406. http://dx.doi.org/10.1016/ j.jenvman.2013.10.008
European Commission. 1995. Wise use and conservation of wetlands. COM (95) 189. European Commission, Brussels, Belgium.

European Commission. 2007. LIFE and Europe's wetlands: restoring a vital ecosystem. Office for Official Publications of the European Communities, Luxembourg.

European Commission. 2015. Reporting under the EU Habitats and Birds Directives 2007-2012. The State of Nature in the EU. Office for Official Publications of the European Union, Luxembourg.

European Environmental Agency (EEA). 2010. EU 2010 biodiversity baseline. EEA, Copenhagen, Denmark.

European Topic Centre for Biological Diversity (ETC/BD). 2008. Habitats Directive Article 17 Report 2000-2006. European Topic Centre for Biological Diversity. [online] URL: http://bd.eionet. europa.eu/activities/Reporting/Article_17/Reports_2007/index_html

Farber, S. 1987. The value of coastal wetlands for protection of property against hurricane wind damage. Journal of Environmental Economics and Management 14:143-151. http://dx. doi.org/10.1016/0095-0696(87)90012-X

Folke, C. 1991. The societal values of wetland life-support. Pages 141-171 in C. Folke and T. Kåberger, editors. Linking the natural environment and the economy: essays from the Eco-Eco Group. Kluwer Academic, Dordrecht, The Netherlands. http://dx.doi. org/10.1007/978-94-017-6406-3_8

Gibbs, J. P. 2000. Wetland loss and biodiversity conservation. Conservation Biology 14:314-317. http://dx.doi.org/10.1046/ j.1523-1739.2000.98608.x

Gilliam, J. W. 1994. Riparian wetlands and water quality. Journal of Environmental Quality 23:896-900. http://dx.doi.org/10.2134/ jeq1994.00472425002300050007x

Gren, I.-M. 1995. The value of investing in wetlands for nitrogen abatement. European Review of Agricultural Economics 22:157-172. http://dx.doi.org/10.1093/erae/22.2.157

Gren, I.-M., C. Folke, K. Turner, and I. Batemen. 1994. Primary and secondary values of wetland ecosystems. Environmental and Resource Economics 4:55-74. http://dx.doi.org/10.1007/BF00691932

Hartig, E. K., O. Grozev, and C. Rosenzweig. 1997. Climate change, agriculture and wetlands in Eastern Europe: vulnerability, adaptation and policy. Climatic Change 36:107-121. http://dx.doi.org/10.1023/a:1005304816660

Hefting, M. M., R. N. van den Heuvel, and J. T. A. Verhoeven. 2013. Wetlands in agricultural landscapes for nitrogen attenuation and biodiversity enhancement: opportunities and limitations. Ecological Engineering 56:5-13. http://dx.doi.org/10.1016/j. ecoleng.2012.05.001

INBO (Research Institute for Nature and Forest). 2015. Biologische Waarderingskaart versie 2. INBO, Brussels, Belgium. [online] URL: http://www.geopunt.be/catalogus/applicationfolder/ biologische-waarderingskaart

Jacobs, S., B. Burkhard, T. Van Daele, J. Staes, and A. Schneiders. 2015. 'The Matrix Reloaded': a review of expert knowledge use for mapping ecosystem services. Ecological Modelling 295:21-30. http://dx.doi.org/10.1016/j.ecolmodel.2014.08.024 
Jacobs, S., N. Dendoncker, B. Martín-López, D. N. Barton, E. Gomez-Baggethun, F. Boeraeve, L. F. McGrath, K. Vierikko, D. Geneletti, J. K. Sevecke, et al. 2016a. A new valuation school: integrating diverse values of nature in resource and land use decisions. Ecosystem Services. http://dx.doi.org/10.1016/j. ecoser.2016.11.007

Jacobs, S., T. Spanhove, L. De Smet, T. Van Daele, W. Van Reeth, P. Van Gossum, M. Stevens, A. Schneiders, J. Panis, H. Demolder, H. Michels, M. Thoonen, I. Simoens, and J. Peymen. 2016b. The ecosystem service assessment challenge: reflections from Flanders-REA. Ecological Indicators 61:715-727. http://dx.doi. org/10.1016/j.ecolind.2015.10.023

Jacobs, S., T. Spanhove, and J. Panis. 2014a. Hoofdstuk 5 Toestand en trend van ecosysteemdiensten in Vlaanderen (INBO. R.2014.6160407). In M. Stevens, H. Demolder, S. Jacobs, H. Michels, A. Schneiders, I. Simoens, T. Spanhove, P. Van Gossum, and W. Van Reeth, editors. Natuurrapport - Toestand en trend van ecosystemen en ecosysteemdiensten in Vlaanderen. Technisch rapport. . Vol. INBO.M.2014.1988582, Instituut voor Natuur- en Bosonderzoek, Brussels, Belgium.

Jacobs, S., T. Spanhove, M. Thoonen, L. De Smet, A. Boerema, K. Van der Biest, and D. Landuyt. 2014b. Hoofdstuk 9 Interacties tussen aanbod, gebruik en vraag van ecosysteemdiensten in Vlaanderen (INBO.R. 2014.6160569). In M. Stevens, H. Demolder, S. Jacobs, H. Michels, A. Schneiders, I. Simoens, T. Spanhove, P. Van Gossum, and W. Van Reeth, editors. Natuurrapport - Toestand en trend van ecosystemen en ecosysteemdiensten in Vlaanderen. Technisch rapport. . Vol. INBO. M.2014.1988582, Instituut voor Natuur- en Bosonderzoek, Brussels, Belgium.

Jacobs, S., W. Verheyden, and N. Dendoncker. In press. Why to map? Guidelines for critical and effective ecosystem service mapping. In M. G. Burkhard, editor. Mapping ecosystem services. Pensoft, Sofia, Bulgaria.

Jeppesen, E., B. Kronvang, J. E. Olesen, J. Audet, M. Søndergaard, C. C. Hoffmann, H. E. Andersen, T. L. Lauridsen, L. Liboriussen, S. E. Larsen, M. Beklioglu, M. Meerhoff, A. Özen, and K. Özkan. 2011. Climate change effects on nitrogen loading from cultivated catchments in Europe: implications for nitrogen retention, ecological state of lakes and adaptation. Hydrobiologia 663:1-21. http://dx.doi.org/10.1007/s10750-010-0547-6

Joao, E. 1998. Causes and consequences of map generalization. Taylor and Francis, London, UK.

Johansson, M., and M. Henningsson. 2011. Social-psychological factors in public support for local biodiversity conservation. Society \& Natural Resources 24:717-733. http://dx.doi. org/10.1080/08941920903530925

Louette, G., D. Adriaens, G. De Knijf, and D. Paelinckx. 2013. Staat van instandhouding (status en trends) habitattypen en soorten van de Habitatrichtlijn (rapportageperiode 2007-2012). Instituut voor Natuur- en Bosonderzoek, Brussels, Belgium.

Nicholls, R. J. 2004. Coastal flooding and wetland loss in the 21st century: changes under the SRES climate and socio-economic scenarios. Global Environmental Change 14:69-86. http://dx.doi. org/10.1016/j.gloenvcha.2003.10.007
Ockenden, M. C., C. Deasy, J. N. Quinton, B. Surridge, and C. Stoate. 2014. Keeping agricultural soil out of rivers: evidence of sediment and nutrient accumulation within field wetlands in the UK. Journal of Environmental Management 135:54-62. http://dx. doi.org/10.1016/j.jenvman.2014.01.015

Persson, J., N. L. G. Somes, and T. H. F. Wong. 1999. Hydraulics efficiency of constructed wetlands and ponds. Water Science and Technology 40:291-300. http://dx.doi.org/10.1016/s0273-1223 (99)00448-5

Russi, D., P. Ten Brink, A. Farmer, T. Badura, D. Coates, J. Föster, R. Kumar, and N. Davidson. 2013. The economics of ecosystems and biodiversity for water and wetlands. IEEP, London, UK and Brussels, Belgium and Ramsar Secretariat, Gland, Switzerland.

Scholte, S. S. K., M. Todorova, A. J. A. van Teeffelen, and P. H. Verburg. 2016. Public support for wetland restoration: What is the link with ecosystem service values? Wetlands 36:467-481. http://dx.doi.org/10.1007/s13157-016-0755-6

Stevens, M., H. Demolder, S. Jacobs, H. Michels, A. Schneiders, I. Simoens, T. Spanhove, P. Vangossum, and W. Vanreeth. 2015. Flanders regional ecosystem assessment: state and trend of ecosystems and their services in Flanders. Synthesis. Research Institute for Nature and Forest, Brussels, Belgium.

Sun, R., A. Chen, L. Chen, and Y. Lü. 2012. Cooling effects of wetlands in an urban region: the case of Beijing. Ecological Indicators 20:57-64. http://dx.doi.org/10.1016/j.ecolind.2012.02.006

Temmerman, S., P. Meire, T. J. Bouma, P. M. J. Herman, T. Ysebaert, and H. J. De Vriend. 2013. Ecosystem-based coastal defence in the face of global change. Nature 504:79-83. http://dx. doi.org/10.1038/nature12859

Thibodeau, F. R. and B. D. Ostro. 1981. An economic analysis of wetland protection. Journal of Environmental Management $12: 19-30$

Thiere, G., S. Milenkovski, P.-E. Lindgren, G. Sahlén, O. Berglund, and S. E. B. Weisner. 2009. Wetland creation in agricultural landscapes: biodiversity benefits on local and regional scales. Biological Conservation 142:964-973. http://dx. doi.org/10.1016/i.biocon.2009.01.006

Tolvanen, A., A. Juutinen, and R. Svento. 2013. Preferences of local people for the use of peatlands: the case of the richest peatland region in Finland. Ecology and Society 18(2):19. http:// dx.doi.org/10.5751/ES-05496-180219

United Nations World Water Assessment Programme (UNWWAP). 2003. Water for people, water for life. UNWWAP, Paris, France.

Van Gossum, P., S. Danckaert, T. Spanhove, and C. Wils. 2014. Hoofdstuk 11 - Ecosysteemdienst voedselproductie. (INBO. R.2014.1987588). In M. Stevens, H. Demolder, S. Jacobs, H. Michels, A. Schneiders, I. Simoens, T. Spanhove, P. Van Gossum, and W. Van Reeth, editors. Natuurrapport - Toestand en trend van ecosystemen en ecosysteemdiensten in Vlaanderen. Technisch rapport. Vol. INBO.M.2014.1988582, Instituut voor Natuur- en Bosonderzoek, Brussels, Belgium.

Verhoeven, J. T. A., B. Arheimer, C. Yin, and M. M. Hefting. 2006. Regional and global concerns over wetlands and water 
quality. Trends in Ecology \& Evolution 21:96-103. http://dx.doi. org/10.1016/j.tree.2005.11.015

VITO. 2014. The Nature Value Explorer v2.2. VITO, Mol, Belgium. [online] URL: https://natuurwaardeverkenner.be/role. jsf

Vlaamse Milieumaatschappij (VMM). 2014a. Milieurapport Vlaanderen: waterkwantiteit. VMM, Aalst, Belgium. [online] URL: http://www.milieurapport.be/nl/feitencijfers/milieuthemas/ waterkwantiteit/

Vlaamse Milieumaatschappij (VMM). 2014b. Overstromingsgevoelige gebieden 2014 (Watertoets). VMM, Aalst, Belgium. [online] URL: http://www.geopunt.be/download?container=

overstromingsgevoelig\&title=Overstromingsgevoelige $\% 20$ gebieden $\%$ 202014\%20(Watertoets

Vos, C. C., D. C. J. van der Hoek, and M. Vonk. 2010. Spatial planning of a climate adaptation zone for wetland ecosystems. Landscape Ecology 25:1465-1477. http://dx.doi.org/10.1007/ s10980-010-9535-5

Vriens, L., H. Bosch, G. De Knijf, S. De Saeger, R. Guelinckx, P. Oosterlynck, M. Van Hove, and D. Paelinckx. 2011. De Biologische Waarderingskaart: biotopen en hun verspreiding in Vlaanderen en het Brussels Hoofdstedelijke Gewest. Instituut voor Natuur- en Bosonderzoek, Brussels, Belgium.

Walters, K. M. and M. Babbar-Sebens. 2016. Using climate change scenarios to evaluate future effectiveness of potential wetlands in mitigating high flows in a Midwestern U.S. watershed. Ecological Engineering 89:80-102 http://dx.doi.org/10.1016/j. ecoleng.2016.01.014

Winter, T. C. 1999. Relation of streams, lakes, and wetlands to groundwater flow systems. Hydrogeology Journal 7:28-45. http:// dx.doi.org/10.1007/s100400050178

Woltemade, C. J. 2000. Ability of restored wetlands to reduce nitrogen and phosphorus concentrations in agricultural drainage water. Journal of Soil and Water Conservation 55:303-309.

Wouters, J., K. Decleer, F. Vanderhaeghe, and M. Hens. 2013. PotNat, een GIS-tool voor het bepalen van de abiotische kansrijkdom van natuurtypen: Deel 1: Methodologie. Instituut voor Natuur- en Bosonderzoek, Brussels, Belgium. 
Appendix 1. Details on the GIS layer sources used for the modeling of wetland loss and their restoration potential in this study

\section{Flemish Soil Map (ALBON 2014)}

- Period of survey: 1947-1970 (mainly 1950's)

- Scale: 1:5,000 (published: 1:20,000).

- Units: soil types according to 11 texture classes, 9 drainage classes, 13 profile development classes, 15 substrate classes

- Use in this study: Abiotic profiles of the different wetland type categories allow the reconstruction of their historical presence based on drainage and texture class.

\section{Biological Valuation Map (INBO 2015, Vriens et al. 2011)}

- Period of survey: $1998-2007$

- Scale: $1: 10,000$

- Units: 180 habitat types including 40 types of wetland habitat, all based on vegetation.

- Use in this study: provides detailed information on the current distribution of wetlands. Abiotic profiles of the different habitat types allow the reconstruction of current drainage class and trophic state.

\section{Flemish Flood Hazard Map (VMM 2014b)}

- Period of survey: 2004-2014

- Scale: 1:10,000

- Units: areas with actual high risk of flooding (i.e. more than one flood in $10 \mathrm{yrs}$ ), based on field observations and hydrodynamic modeling.

- Use in this study: provides information on regularly flooded areas (7,5\% of Flanders), which can be natural (river valleys) or antropogenic (flooded areas due to changes in local urbanization and soil sealing). By excluding urban areas and arable land, the flood hazard map gives a picture where some biological value may still be present such as semi-natural vegetation relicts or at least temporary presence of (wintering) waterfowl. The map provides additional information to the Biological Valuation map for delineation of current wetlands.

\section{Historic Forest Map (De Keersmaeker et al. 2001)}

- Period of survey: topographic maps surveyed in the period 1910-1940

- Scale: $1: 20,000$

- Units: forested areas ( as detected by semi-automatic image recognition)

- Use in this study: reconstruction of land use of historic wetlands

\section{Tidal Marsh Maps}

The actual distribution of tidal marshes was derived from the Biological Valuation Map. The historic distribution of tidal marshes along the river Schelde was based on the situation around 1960 as described by Van Braeckel et al. (2012). The potential for restoration of tidal marshes along the river Schelde was based on Van den Bergh et al. (2003). Actual and historic distribution of tidal marshes outside the area under influence of the river Schelde were the same.

\section{POTNAT (Wouters et al. 2013)}

- Integrated maps derived from different information sources by GIS modeling and grid transformation

- Scale: $20 \times 20 \mathrm{~m}$ grid cells

- Units: maps with the potentials for restoration of 18 terrestrial wetland habitat types under current (mainly Biological Valuation Map) and past (mainly Flemish Soil Map) abiotic conditions

- Use in this study: distribution of wetlands that can be restored or created, assuming that on the long term 
historic abiotic conditions can more or less be restored. Urbanized areas and running waters were excluded.

\section{Flemish Land Use Map (Poelmans \& Van Daele 2014)}

- Integrated map, derived from different information sources with grid transformation

- Scale: $10 \times 10 \mathrm{~m}$ grid cells

- Units: 23 land use classes, such as urban areas, production forest and semi-natural forest, permanent production grassland, semi-natural grassland, marshes, heathlands, alder-willow forests, tidal marshes and standing waters.

- Use in this study: current distribution of urban areas (including gardens) and forested areas 
Appendix 2. Consequences of adopting the legally obliged 'stand still principle' for the calculation of the total area (in hectares) for two scenarios of potential wetland.

Actual forested wetlands Actual open wetlands Actual forested areas with nature value and wetland potential

Actual open areas with nature value and wetland potential Actual forested areas with low nature value and wetland potential (production forests) Actual open areas with low nature value, and wetland potential

(arable land, species-poor grasslands)

Adoption of the
stand still
principle
yes
yes
yes
yes
no
no

Potential wetlands (open landscape)

Area 'as is'

-

Area 'as is' (but sites will become wetter) Total area becomes open landscape wetland Total area becomes open landscape wetland
Potential wetlands

(forested landscape)

Area 'as is'

Area 'as is' (but sites will become wetter)

Total area becomes forested wetland

Total area becomes forested wetland 


\section{Appendix 3. Monetary Quantification and valuation methods}

\section{WATER RETENTION}

Quantification: Water retention occurs at sites that are at least temporarily waterlogged. Many of these waterlogged sites have been drained for agriculture, housing etc... We quantify the retention as the mean level of water saturation in the topsoil (\% waterlogged up to 1 meter depth). In combination with the soil porosity, we can express this as a retention volume $\left(\mathrm{m}^{3}\right)$ per area unit. Potential water retention is derived from a) Mean historical high water levels, interpolated from soil data (indication of the depth of oxidation- reduction fronts); b) information on infiltration-seepage patterns at multiple scales, which is derived from a multi-scale topographic position index on a high resolution DEM (Jenness 2006, De Reu et al. 2013). Actual retention is limited by drainage intensity, which is derived from land-use intensity (desired drainage depth) and drainage network density (distance decay principle).

Valuation: Valuation of additional water retention was explored from two viewpoints. The first is the substitution cost: In times of scarcity, water is purchased in the Walloon region. A recent benchmark study of the drinking water companies revealed the average additional costs of purchasing treated water versus own production at the level of the Flemish Region. This difference in costs is approximately $0.2 € / \mathrm{m}^{3}$. The second method used is based on the groundwater water abstraction tax. This tax is $0.075 € / \mathrm{m}^{3}$ and can be seen as a compensation for the environmental and resource costs as formulated within the Water Framework Directive. This is the existing effective contribution from water companies and should be regarded as the absolute bottom threshold.

\section{AGRICULTURAL PRODUCTION}

Quantification: Because of the nature of the primary data, quantification is done directly in $€ /$ ha* $y r$. Typical agricultural net revenues per crop type are derived from sample data on profits and loss accounts at the farm level. These values are then used in combination with the parcel level crop registration data of 2010 and crop specific soil suitability maps to account for spatial variations in crop specific productivity. The profits and loss accounts reflect the state of revenues and costs for particular agricultural sectors. The net revenue is the difference between the total revenue from agricultural production (excluding subsidies) minus the operational costs. For the year 2010 this was derived from detailed data from a random check of 749 particular farms (Van Broekhoven E. 2010). Because of the variability between years we used data from 2008, 2009 and 2010 to estimate the values per crop type. For fodder crop types, an alternative method is used by the agricultural administration (D'Hooghe 2012 ). In general, fodder crops are not sold on the market, but are used as fodder within the agricultural production chain. The net revenues from dairy and meat production are therefore distributed among the fodder production parcels at the farm level to estimate a revenue factor for fodder crops. Based on this data, a P25, P50 and P75 revenue value (per ha) was derived for the most important crop types (e.g. for corn P25=€ 1.245, P50=€1.580, P75=€1.818).

The soil suitability maps for agriculture and horticulture are based on the digital soil map of Belgium (Dudal et al. 2005) A suitability class groups the soil types that can provide a comparable production for several crop types when uniform cultivation and fertilization practices are applied. For each crop type, a 5 class ranking is provided, where class 1 is very suitable and class 5 is unsuitable (Bollen 
2012). The classes 1-2 are associated with the P75 values of the crop revenue values, the classes 3-4 are associated with the P50 values and class 5 is associated with the P25 values.

\section{WOOD PRODUCTION}

Quantification: Wood production depends on soil characteristics and applied harvest regime. Species specific potential produced wood volumes can be found in table A.1, where differentiation is made according to the soil suitability.

Table A1: Overview of the relationships between soil suitability and the maximal mean growth of stemwood $\left(\mathrm{m}^{3} / \mathrm{ha}^{*} \mathrm{yr}\right)$.

\begin{tabular}{|c|c|c|c|c|c|c|c|c|}
\hline \multirow{2}{*}{ Soil suitability } & \multicolumn{9}{|c|}{ Tree species } \\
\cline { 2 - 10 } & $\begin{array}{c}\text { Fagus } \\
\text { sylvatica }\end{array}$ & $\begin{array}{c}\text { Quercus } \\
\text { (Robur, Rubra) }\end{array}$ & Populus & $\begin{array}{c}\text { Larix } \\
\text { decidua }\end{array}$ & $\begin{array}{c}\text { Pinus } \\
\text { sylvestris }\end{array}$ & $\begin{array}{c}\text { Pinus Nigra } \\
\text { Picea abies }\end{array}$ & $\begin{array}{c}\text { Pseudotsuga } \\
\text { menziesii }\end{array}$ \\
\hline 4 & 4.0 & 3.0 & 9.0 & 6.0 & 4.0 & 6.0 & 6.0 & 8.0 \\
\hline 3 & 6.7 & 5.0 & 11.0 & 8.7 & 6.0 & 9.3 & 9.0 & 10.7 \\
\hline 2 & 9.3 & 7.0 & 13.0 & 11.3 & 8.0 & 12.7 & 13.0 & 13.3 \\
\hline 1 & 12.0 & 9.0 & 15.0 & 14.0 & 10.0 & 16.0 & 16 & 16.0 \\
\hline
\end{tabular}

Depending on management and ownership structure (private, public) a harvest factor is applied that estimates the proportion of the annual maximal mean growth that is harvested annually. The harvested volumes are available from recent data (2009-2012) on timber selling from public (state owned) forests and from forest owner cooperatives (privately owned, but the management is state coordinated). This data base has about 80.000 records of sold volumes per tree species and circumferences. For state owned forests, the harvest factor is 0.54 . Privately owned forests are often unmanaged and have a lower (0.15) harvest factor. For private forests, there is an unknown fraction of harvest for private use and informal markets (especially for fire wood).

Valuation: Valuation of wood production has been done on the basis of annual $\mathrm{m}^{3}$ harvest per year and per tree species. The value for each species was based on the database of actual selling prices in the state-owned forests for the years 2009-2012. Although the records refer to tree species, volumes and associated circumferences, the selling prices often refer to a combination of several records sold as one single lot (in average 18 records/lot). Statistical analysis (SPSS 20.0) was used to reveal a selling price $\left(€ / \mathrm{m}^{3}\right)$ per species and circumference class (Table A.2). The average weighted selling price for all species and circumferences was estimated at $32.43 € / \mathrm{m}^{3}$. Trees are sold as standing timber and prices are therefore considered as net added value of timber production.

Table A2: Overview of timber values $\left(€\right.$ per $\mathrm{m}^{3}$ ) sold as standing timber per circumference class for most important commercial tree species.

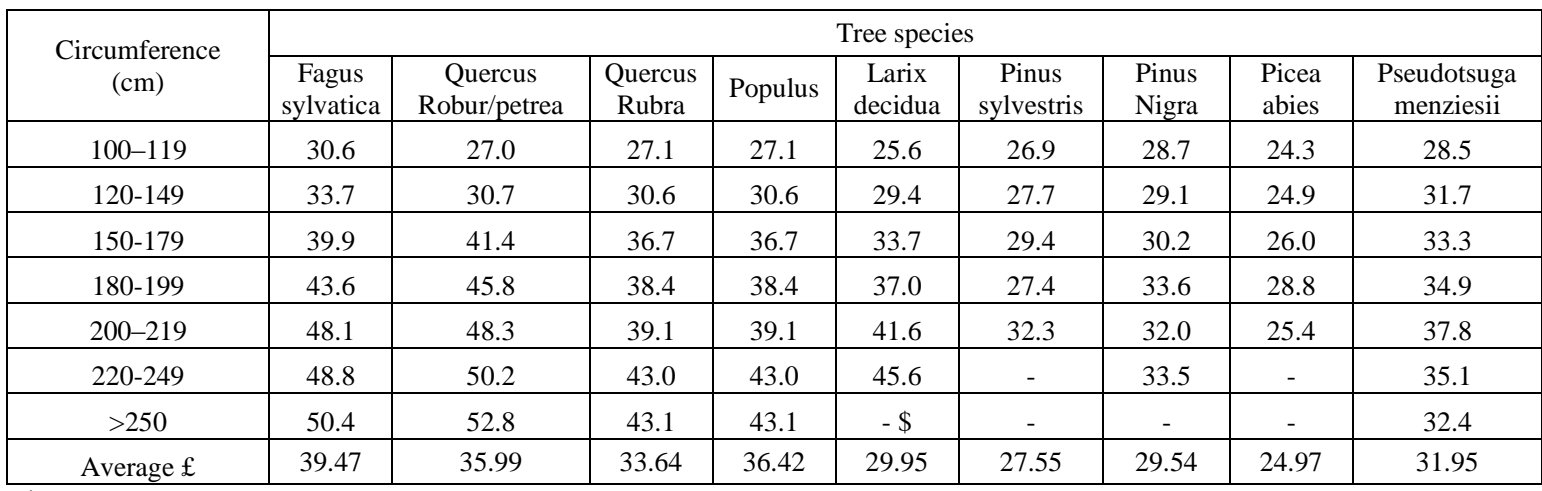

$\$$ : $\mathrm{n}<10$ unrealiable parameter estimation;

$\mathrm{f}$ : weighted mean, based on number of observations per circumference 


\section{CARBON SEQUESTRATION IN SOILS}

Quantification: Soils under unmanaged, natural vegetation types typically have larger carbon stocks than managed vegetation types. Also soil hydrology plays a crucial role in the creation of soil organic carbon (SOC) stocks. Soil organic carbon is especially high for forests and/or hydric soils. The potential equilibrium state for soil organic carbon stocks can be calculated using the regression formula by Meersmans et. al. (2008), which includes parameters like water retention, soil texture and vegetation type. Changes in land-use typically affect both vegetation and/or drainage (ES water retention), which leads to a new potential equilibrium state for SOC stocks. Recent research by Dr. De Vos (2009) has revealed that this function systematically underestimated SOC-stocks in forest soils with $32 \%$. This correction factor to the regression formula of Meersmans is applied to all forests. Peatlands, wetlands and freshwater ecosystems can sequester higher carbon stocks than terrestrial ecosystems. Potential (maximal) stocks are very much dependent on hydrological regimes and how mature these ecosystems are. Depending on the hydrological regime, newly created wetlands sequester 2.5-3.5 ton C/ha*yr in the first 100 years. Older wetland systems often do not sequester much additional carbon, especially when they are not under permanent hydric conditions. On the other hand, pulsed hydrological conditions emit less methane.

Valuation: Stocks are difficult to consider in valuation exercises. Here we calculated a virtual scenario of changes in carbon stocks due to changes in land use (habitat types) and associated changes in water retention. The difference in SOC stocks would be gradually built or released at a rate of $2.5 \%$ loss per year. The valuation method is identical to the valuation of carbon sequestration in biomass.

\section{AVOIDED NITRATE LEACHING}

Quantification: It can be debated if the cessation of fertilizer use can be categorized as an ES. It is imperative to include this since landscape level nutrient leaching is an important parameter for the ES "nutrient removal by denitrification". Infiltration on fertilized agricultural land results in nitrate leaching to groundwater and eventually surface water. Important variables are the specific combinations of soil texture, crop type, agricultural fertilizer application ( $\mathrm{kg} \mathrm{N} / \mathrm{ha}$ ) and atmospheric $\mathrm{N}$-deposition ( $\mathrm{kg} \mathrm{N} / \mathrm{ha}$ ). Long-term data on autumn and spring nitrate residues in agricultural soils were available from the Flemish Land Agency (Geypens et al. 2005). The difference between fall and spring residue is assumed to be leached out by winter precipitation. Atmospheric nitrogen deposition data were provided by the Flemish Environment Agency (FEA 2011). We assumed that nutrient leaching also occurs on non-agricultural land with high deposition rates. Although declining, these values are still relatively high (Staelens et al. 2012). From the data on nutrient leaching from agricultural land we know these values range between $7 \%$ and $33 \%$ of the nitrate application. We applied the same range of values (7 - $33 \%$ ) on non-agricultural land with $\mathrm{N}$-deposition and varied the range of values accordingly to the natural sensitivity for nitrate leaching (soil texture). 
Table A3: parameter values for maximal fertilizer application, fall nitrate residues in soils and winter nitrate leaching in function of cultivation and soil texture.

\begin{tabular}{|c|c|c|c|c|c|c|}
\hline Cultivation & Texture & $\begin{array}{c}\text { Max. N- } \\
\text { application kg } \\
\text { N/ha }\end{array}$ & N-residue fall & $\begin{array}{c}\text { Relative } \\
\text { residue (\%) }\end{array}$ & N-leaching & $\begin{array}{c}\text { Relative } \\
\text { leaching (\%) }\end{array}$ \\
\hline pasture & sand & 350 & 60 & $17 \%$ & 32 & $9 \%$ \\
\hline pasture & loam & 370 & 67 & $18 \%$ & 26 & $7 \%$ \\
\hline pasture & clay & 380 & 73 & $19 \%$ & 23 & $6 \%$ \\
\hline beet (fodder) & sand & 305 & 49 & $16 \%$ & 30 & $10 \%$ \\
\hline beet (fodder) & loam & 330 & 55 & $17 \%$ & 24 & $7 \%$ \\
\hline beet (fodder) & clay & 330 & 60 & $18 \%$ & 21 & $6 \%$ \\
\hline maize & sand & 205 & 86 & $42 \%$ & 57 & $28 \%$ \\
\hline maize & loam & 220 & 96 & $44 \%$ & 40 & $18 \%$ \\
\hline maize & clay & 220 & 105 & $48 \%$ & 41 & $19 \%$ \\
\hline barley and other cereals & sand & 200 & 69 & $35 \%$ & 42 & $21 \%$ \\
\hline barley and other cereals & loam & 215 & 77 & $36 \%$ & 33 & $15 \%$ \\
\hline barley and other cereals & clay & 215 & 84 & $39 \%$ & 30 & $14 \%$ \\
\hline wheat and tricitale & sand & 250 & 80 & $32 \%$ & 42 & $17 \%$ \\
\hline wheat and tricitale & loam & 264 & 89 & $34 \%$ & 33 & $13 \%$ \\
\hline wheat and tricitale & clay & 265 & 98 & $37 \%$ & 29 & $11 \%$ \\
\hline crops with low N-demand & sand & 165 & 69 & $42 \%$ & 42 & $25 \%$ \\
\hline crops with low N-demand & loam & 175 & 76 & $44 \%$ & 33 & $19 \%$ \\
\hline crops with low N-demand & clay & 175 & 84 & $48 \%$ & 29 & $17 \%$ \\
\hline other & sand & 50 & 9 & $18 \%$ & 5 & $10 \%$ \\
\hline other & loam & 50 & 10 & $20 \%$ & 4 & $8 \%$ \\
\hline other & clay & 50 & 11 & $22 \%$ & 4 & $8 \%$ \\
\hline Vegetables Group II & sand & 180 & 86 & $48 \%$ & 53 & $29 \%$ \\
\hline Vegetables Group II & loam & 180 & 96 & $53 \%$ & 41 & $23 \%$ \\
\hline Vegetables Group II & clay & 180 & 105 & $58 \%$ & 37 & $21 \%$ \\
\hline potatoes & sand & 280 & 111 & $40 \%$ & 68 & $24 \%$ \\
\hline potatoes & loam & 280 & 124 & $44 \%$ & 53 & $19 \%$ \\
\hline potatoes & clay & 280 & 136 & $49 \%$ & 48 & $17 \%$ \\
\hline Sugar beet & sand & 205 & 54 & $26 \%$ & 33 & $16 \%$ \\
\hline Sugar beet & loam & 220 & 60 & $27 \%$ & 26 & $12 \%$ \\
\hline Sugar beet & clay & 220 & 66 & $30 \%$ & 23 & $10 \%$ \\
\hline Vegetables Group III & sand & 125 & 66 & $53 \%$ & 40 & $32 \%$ \\
\hline Vegetables Group III & loam & 125 & 74 & $59 \%$ & 32 & $26 \%$ \\
\hline Vegetables Group III & clay & 125 & 81 & $65 \%$ & 28 & $22 \%$ \\
\hline Vegetables Group I & sand & 250 & 114 & $45 \%$ & 69 & $28 \%$ \\
\hline Vegetables Group I & loam & 250 & 126 & $50 \%$ & 54 & $22 \%$ \\
\hline Vegetables Group I & clay & 250 & 139 & $56 \%$ & 49 & $20 \%$ \\
\hline crops & sand & 200 & 90 & $45 \%$ & 55 & $28 \%$ \\
\hline crops & loam & 215 & 100 & $46 \%$ & 43 & $20 \%$ \\
\hline crops & clay & 215 & 110 & $51 \%$ & 38 & $18 \%$ \\
\hline legumes (other than peas and beans) & sand & 120 & 39 & $32 \%$ & 24 & $20 \%$ \\
\hline legumes (other than peas and beans) & loam & 125 & 43 & $35 \%$ & 19 & $15 \%$ \\
\hline legumes (other than peas and beans) & clay & 125 & 48 & $38 \%$ & 17 & $14 \%$ \\
\hline
\end{tabular}

Valuation: see below section on nutrient removal by denitrification.

\section{NUTRIENT REMOVAL BY DENITRIFICATION}

Quantification: Under conditions of (temporal) waterlogging, bacterial processes enable to remove nitrogen from ground and surface water. The most important variables are the soil moisture, supply of nitrate, residence time and soil organic carbon. As a proxy for nitrate removal efficiency, we transform combinations of the mean highest (MHG) and mean lowest groundwater (MLG) levels to an estimated nitrate removal efficiency (\% of available nitrate removed). 
Table A4: Estimated removal efficiency (\%) for combinations of mean highest and mean lowest groundwater levels (in $\mathrm{cm}$ below soil surface).

\begin{tabular}{|c|c|c|c|c|c|c|c|c|c|c|c|}
\hline & MLG & $>50$ & 45 & 40 & 35 & 30 & 25 & 20 & 15 & 10 & $5-0$ \\
\hline MHG & & & & & & & & & & & \\
\hline$>50$ & & 10 & 13 & 17 & 20 & 23 & 27 & 30 & 33 & 37 & 40 \\
\hline 45 & & & 20 & 23 & 27 & 30 & 33 & 37 & 40 & 43 & 47 \\
\hline 40 & & & & 30 & 33 & 37 & 40 & 43 & 47 & 50 & 53 \\
\hline 35 & & & & & 40 & 43 & 47 & 50 & 53 & 57 & 60 \\
\hline 30 & & & & & & 50 & 53 & 57 & 60 & 63 & 67 \\
\hline 25 & & & & & & & 60 & 63 & 67 & 70 & 73 \\
\hline 20 & & & & & & & & 70 & 73 & 77 & 80 \\
\hline 15 & & & & & & & & & 80 & 83 & 87 \\
\hline 10 & & & & & & & & & & 90 & 93 \\
\hline $0-5$ & & & & & & & & & & & 100 \\
\hline
\end{tabular}

Nitrogen has many and complex pathways by which it is dispersed in the environment. For this study, we focus on the issue of excess nitrogen in groundwater and surface water. Nutrient leaching from agricultural land is one of the major pathways. Reduction of nitrate leaching has already been described in previous sections, but is an important variable for denitrification. For the current situation, the avoided nitrate leaching is zero. But the NCO's include both cessation of fertilizer application and cessation of drainage. Cessation of nitrate leaching implies a decrease of nitrate supply to the denitrification zones, which in their turn may have increased nitrate removal efficiency due to rewetting. The supply of nitrogen occurs through patterns of (local) infiltration (nitrate leaching) and seepage. Infiltration and seepage patterns are the result of processes that occur on a range of spatial scales. A topographic position index (TPI) is used to identify these patterns at multiple scales (Jenness 2006). This method has also been used in other studies for the Flemish Region and has proven its applicability (De Reu et al. 2013). We calculated the TPI at a range of spatial scales (radius: $250 \mathrm{~m}-2000 \mathrm{~m}$ ) to indicate these local infiltration-seepage patterns. The multiscale TPI is then corrected for soil permeability to result in a seepage intensity map, indicating the water supply to a particular pixel ( $\mathrm{mm} / \mathrm{day})$. The nitrate concentration of the supplied seepage water is calculated at the landscape level ( $2 \mathrm{~km}$ radius) by multiplying the annual nitrate leaching ( $\mathrm{kg} \mathrm{N} / \mathrm{ha}$ ) with the annual infiltration ( $\mathrm{m}^{3} / \mathrm{ha}$ ). This allows us to calculate denitrification by multiplying the removal efficiency with the annual nitrate load for each pixel.

Valuation: The valuation is based on the marginal reduction cost for nitrate removal. The Environmental Costing Model for Flanders compares different (technical) measures on cost-efficiency $(€ / \mathrm{kg}$ reduction) and the applicability of those measures. The cost of the most expensive measure, considered in policy approved measure programs, can be seen as the cost the society is willing to pay for a further reduction of nitrate levels in ground and surface water. For nitrate, the marginal reduction cost is $74 € / \mathrm{kg} \mathrm{N}$. As a low estimate we apply $5 € / \mathrm{kg} \mathrm{N}$, based on a literature review (Cools et al. 2011, Broekx et al. 2013a, Broekx et al. 2013b). 


\section{REFERENCES:}

Bollen, B. 2012. Optimalisatie van de bodemgeschiktheidskaart op basis van de drainage en textuurklasse. Publicatie van het departement Landbouw \& Visserij, afdeling Duurzame Landbouwontwikkeling.

Broekx, S., L. De Nocker, I. Liekens, L. Poelmans, J. Staes, K. Van der Biest, P. Meire, and K. Verheyen. 2013a. Estimate of the benefits delivered by the Flemish Natura 2000 network. Study carried out on the authority of the Agency for Nature and Forests (ANB/IHD/11/03) by VITO, Universiteit Antwerpen and Universiteit Gent 2013/RMA/R/87 (March 2013)

Broekx, S., I. Liekens, W. Peelaerts, L. De Nocker, D. Landuyt, J. Staes, P. Meire, M. Schaafsma, W. Van Reeth, O. Van den Kerckhove, and T. Cerulus. 2013b. A web application to support the quantification and valuation of ecosystem services. Environmental Impact Assessment Review 40:65-74.

Cools, J., S. Broekx, V. Vandenberghe, H. Sels, E. Meynaerts, P. Vercaemst, P. Seuntjens, S. Van Hulle, H. Wustenberghs, W. Bauwens, and M. Huygens. 2011. Coupling a hydrological water quality model and an economic optimization model to set up a cost-effective emission reduction scenario for nitrogen. Environmental Modelling \& Software 26:44-51.

D'Hooghe, J. 2012 Berekeningsmethode baten ruwvoeders. Nota uitgewerkt in het kader van deze studie door het departement landbouw en visserij, afdeling monitoring en studie.

De Reu, J., J. Bourgeois, M. Bats, A. Zwertvaegher, V. Gelorini, P. De Smedt, W. Chu, M. Antrop, P. De Maeyer, P. Finke, M. Van Meirvenne, J. Verniers, and P. Crombé. 2013. Application of the topographic position index to heterogeneous landscapes. Geomorphology 186:39-49.

De Vos, B. 2009. Uncertainties of forest soil carbon stock assessment in Flanders. Doctoral dissertation no. 865 of the Faculty of Bioscience Engineering. K.U.Leuven. 318 p.

Dudal, R., J. Deckers, J. V. Orshoven, and E. V. Ranst. 2005. Soil Survey in Belgium and its Applications. $N^{\circ}$ 9, Office for Official publications of the European Communities Luxembourg.

FEA. 2011. Flemish Environment Agency, Air Quality in Flanders - Acidifying atmospheric depostions in the Flemisch Region (http://www.vmm.be/pub/luchtkwaliteit-in-vlaanderen-2013-zureregen-in-vlaanderen-in-2011/view).

Geypens, M., J. Mertens, P. V. Elst, and J. Bries. 2005. Evaluation of fall residual nitrogen influenced by soil chemical characteristics and crop history in Flanders (Belgium). Communications in Soil Science and Plant Analysis 36:363-372.

Jenness, J. S. 2006. Topographic Position Index (tpi_jen.avx) extension for ArcView 3.x, v. 1.3a. Jenness Enterprises. Available at: http://www.jennessent.com/arcview/tpi.htm.

Meersmans, J., F. De Ridder, F. Canters, S. De Baets, and M. Van Molle. 2008. A multiple regression approach to assess the spatial distribution of Soil Organic Carbon (SOC) at the regional scale (Flanders, Belgium). Geoderma 143:1-13.

Staelens, J., K. Wuyts, S. Adriaenssens, P. Van Avermaet, H. Buysse, B. Van den Bril, E. Roekens, J. P. Ottoy, K. Verheyen, O. Thas, and E. Deschepper. 2012. Trends in atmospheric nitrogen and sulphur deposition in northern Belgium. Atmospheric Environment 49:186-196.

Van Broekhoven E., S. L. T. B. 2010. Overzicht van de boekhoudkundige resultaten van 749 land- en tuinbouwbedrijven Boekjaar 2010 Landbouwmonitoringsnetwerk, Beleidsdomein Landbouw en Visserij, afdeling Monitoring en Studie, Brussel. 


\section{Appendix 4:}

\section{Historical wetlands in Flanders ( \pm 1950)}

not wet

deep water

shallow waters (oligo-mesotrophic, eutrophic)

tempwet: temporary wet soil (meso-eutrophic) - non-forested

tempwet: temporary wet soil (meso-eutrophic) - forested

permwet: permanent wet soil (meso-eutrophic) - non-forested

permwet: permanent wet soil (meso-eutrophic) - forested

tempwet: temporary wet soil (oligotrophic) - non-forested

tempwet: temporary wet soil (oligotrophic) - forested

permwet: permanent wet soil (oligotrophic) - non-forested

permwet: permanent wet soil (oligotrophic) - forested

tidal marsh - non-forested

tidal marsh - forested

watercourse

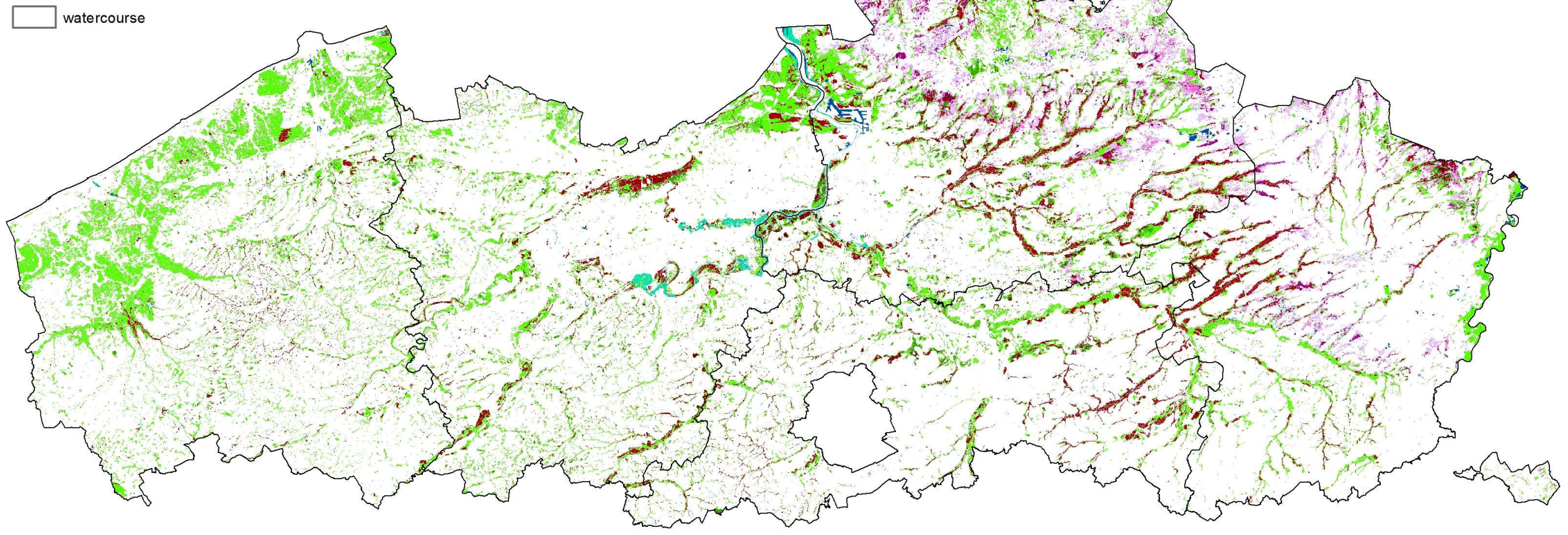




\section{Appendix 5.}

\section{Actual wetlands in Flanders}

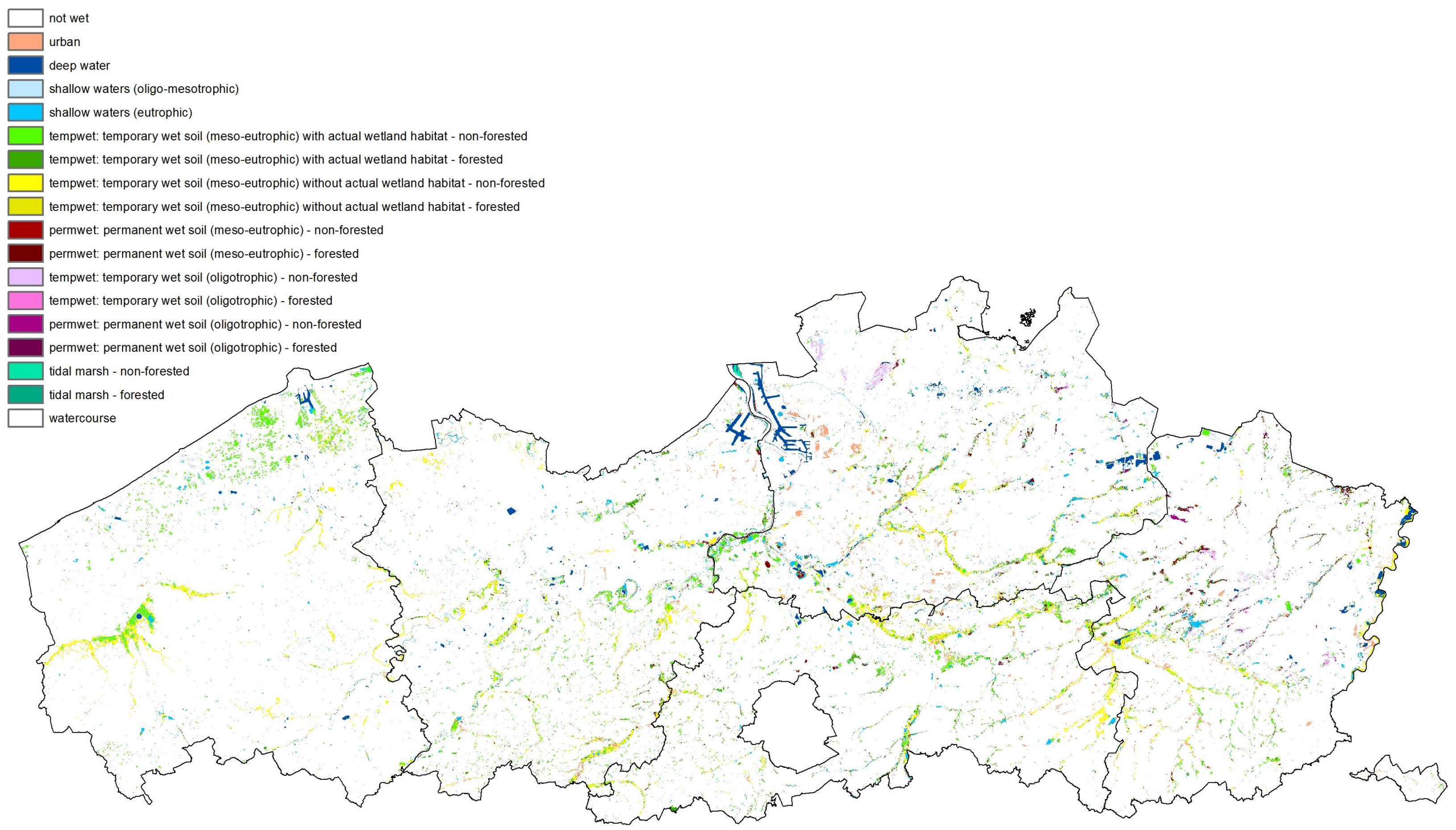


Appendix 6.

\section{Potential wetlands in Flanders: non-forested scenario}

\section{$\square$ not wet}

urbanized wetlands

deep water

shallow waters (oligo-mesotrophic, eutrophic)

tempwet: temporary wet soil (meso-eutrophic) outside natural floodplain areas - non-forested

tempwet: temporary wet soil (meso-eutrophic) outside natural floodplain areas - forested

tempwet temporary wet soil (meso-eutrophic) - non-forested

tempwet. temporary wet soil (meso-eutrophic) - forested

permwet. permanent wet soil (meso-eutrophic) - non-forested

permwet: permanent wet soil (meso-eutrophic) - -forested tempwet: temporary wet soil (oligotrophic) - non-forested

tempwet: temporary wet soil (oligotrophic) - forested

permwet permanent wet soil (oligotrophic) - non-forested

permwet: permanent wet soil (oligotrophic) - forested

tidal marsh - non-forested

tidal marsh - forested

watercourse
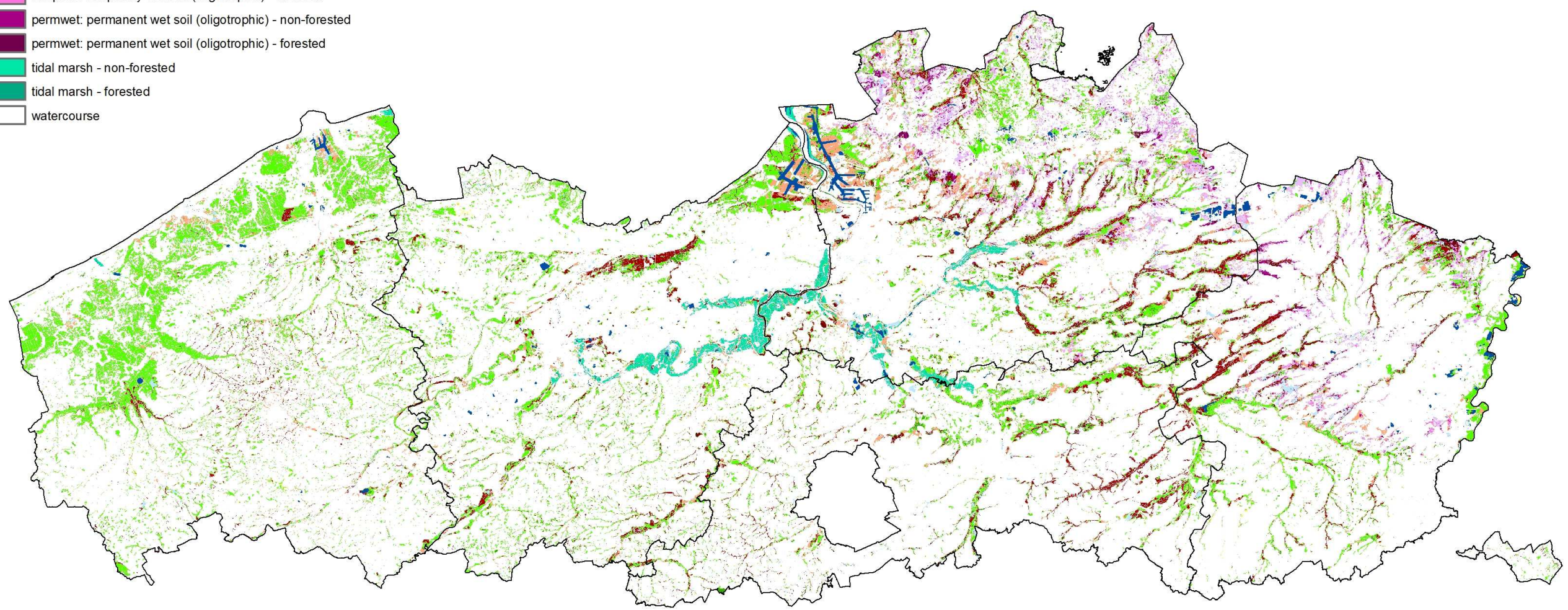
Appendix 7.

\section{Potential wetlands in Flanders: Forested scenario}

$\square$ not wet

deep water

shallow waters (oligo-mesotrophic, eutrophic)

tempwet: temporary wet soil (meso-eutrophic) outside natural floodplain areas - non-forested

tempwet: temporary wet soil (meso-eutrophic) outside natural floodplain areas - forested

tempwet: temporary wet soil (meso-eutrophic) - non-forested

tempwet: temporary wet soil (meso-eutrophic) - forested

permwet: permanent wet soil (meso-eutrophic) - non-forested

permwet: permanent wet soil (meso-eutrophic) - forested

tempwet temporary wet soil (oligotrophic) - non-forested

tempwet: temporary wet soil (oligotrophic) - forested

permwet: permanent wet soil (oligotrophic) - non-forested

permwet: permanent wet soil (oligotrophic) - forested

tidal marsh - non-forested

tidal marsh - forested

watercourse

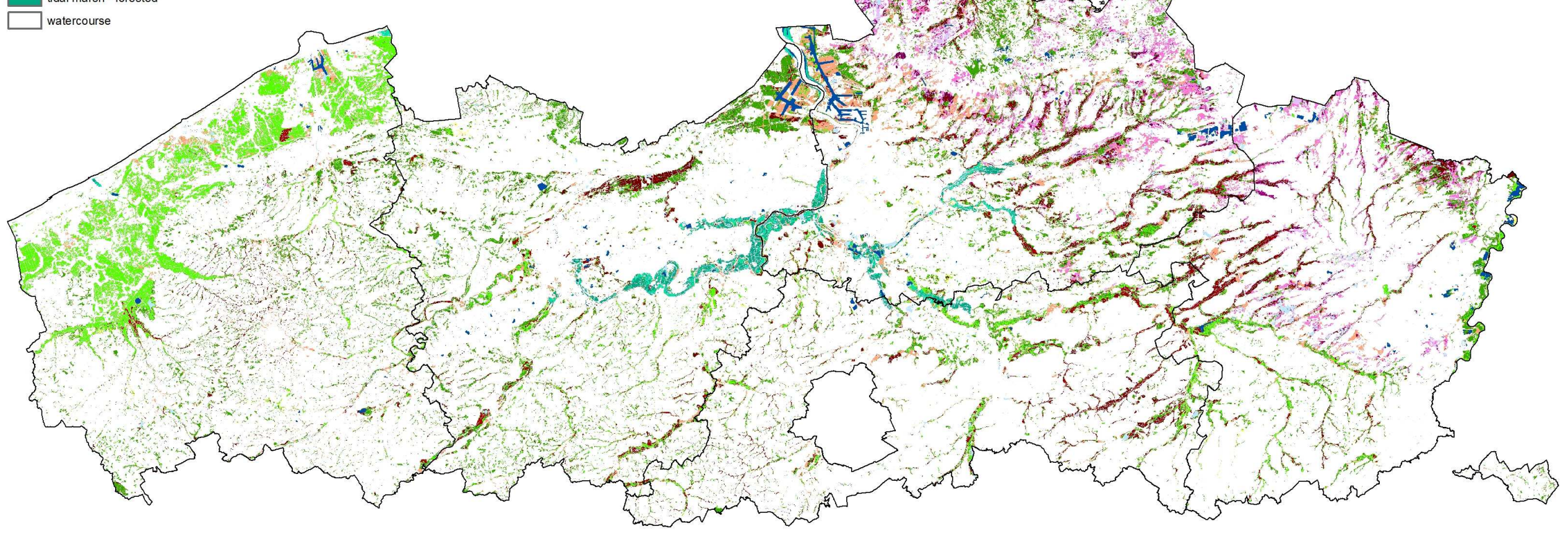




\section{Appendix 8. Past and current water management policy in Flanders and the protection status of actual and potential wetlands}

The organization of hydrological and water level management in Flanders has always been very complex with many actors on different government and administrative levels and a total lack of overall coordination. In the past the focus of each actor has always been on draining wet soils and evacuation of surplus water to the sea as fast as possible. A large proportion of Flemish rivers and water courses has been widened, straightened and embanked from the 1950s onwards. Powerful pumps were installed to drain wetlands and artificially control water levels. It became custom practice that in the so-called 'water-sick' areas the water levels were kept very low during winter, while in summer irrigation water was supplied to create an optimal water level for agriculture. Farmers of historic wetland areas were (and still are) organized in local water boards (so-called 'polders en wateringen') with a mission to improve agricultural exploitation, financially supported by the government. These local water boards cover 208,000 ha of Flanders. Furthermore, intensification of agriculture and improved drainage was facilitated by large-scale land consolidation programs in 150,000 ha or $12 \%$ of Flanders.

Mind setting started to change from 2003 onwards with the approval of the Flemish Decree on integrated water policy, which was initiated by the European Water Framework Directive (2000). Meanwhile the socio-economic problems caused by extreme flood events due to artificially improved drainage, soil sealing and climate change were recognized and more interest for wetland restoration and floodplain functioning was observed in the different governmental layers and media. The once common practice of widening and straightening of rivers, as well as urbanization of irregularly flooded areas has virtually stopped. Still, of the current 68,000 ha of remaining wetland only about 44,000 ha is protected by Flemish or EU regulations (nature zones in spatial planning maps, Birds- or Habitats Directive and Ramsar sites). For the 147,000 ha of potential wetland on top of actual wetland we found that one third of the area or 49,000 ha already has the appropriate spatial planning and protection status to justify wetland restoration (see Table 1).

Table 1. Spatial planning and protection status of actual and two scenarios of potential wetlands in Flanders for several categories of wetlands (in ha). Note that for shallow and deep waters values are identical because no potentials could be calculated. 


\begin{tabular}{|c|c|c|c|c|c|c|}
\hline & \multicolumn{2}{|c|}{ Actual wetland } & \multicolumn{2}{|c|}{$\begin{array}{c}\text { potential wetland } \\
\text { (forested landscape } \\
\text { scenario) }\end{array}$} & \multicolumn{2}{|c|}{$\begin{array}{c}\text { potential wetland (open } \\
\text { landscape scenario) }\end{array}$} \\
\hline & area & protected & area & protected & area & protected \\
\hline deep water & 6.824 & 2.238 & 6.823 & 2.238 & 6.823 & 2.238 \\
\hline shallow water oligo-mesotrophic & 1.408 & 1.314 & \multirow{2}{*}{11.266} & \multirow{2}{*}{7.212} & \multirow{2}{*}{11.266} & \multirow{2}{*}{7.212} \\
\hline shallow water eutrophic & 9.858 & 5.898 & & & & \\
\hline temporary wet soil (meso-eutrophic) - open & 34.676 & 21.466 & 47.687 & 19.486 & 109.457 & 34.534 \\
\hline temporary wet soil (meso-eutrophic) - forested & 6.389 & 5.196 & 70.997 & 21.961 & 9.227 & 6.913 \\
\hline temporary wet soil (oligotrophic) - open & 1.295 & 1.287 & 2.622 & 2.229 & 21.800 & 9.069 \\
\hline temporary wet soil (oligotrophic) - forested & 597 & 570 & 23.858 & 10.729 & 4.680 & 3.890 \\
\hline permanently wet soil (meso-eutrophic) - open & 2.576 & 1.936 & 11.856 & 8.027 & 29.582 & 13.925 \\
\hline permanently wet soil (meso-eutrophic) - forested & 2.802 & 2.419 & 24.579 & 11.435 & 6.853 & 5.537 \\
\hline permanently wet soil (oligotrophic) - open & 256 & 254 & 950 & 849 & 3.044 & 1.775 \\
\hline permanently wet soil (oligotrophic) - forested & 539 & 524 & 3.687 & 2.356 & 1.594 & 1.430 \\
\hline tidal marsh - open & 566 & 556 & 3.758 & 2.682 & 9.335 & 5.310 \\
\hline tidal marsh - forested & 103 & 101 & 6.344 & 3.183 & 767 & 555 \\
\hline TOTAL & 67.889 & 43.759 & 214.427 & 92.388 & 214.427 & 92.388 \\
\hline
\end{tabular}

Nowadays, some of the most prestigious nature restoration projects in Flanders go hand in hand with flood protection:

- More than 1,800 ha of brackish and fresh water tidal marshes are currently being restored along the river Schelde, simultaneously providing areas for flood control (Beauchard et al. 2011, Jacobs et al. 2009, Temmerman et al. 2013). After the deepening of the river Zeeschelde for better navigation access to the port of Antwerp ecological compensations were imposed on the Flemish government by the European Commission, including nearly 600 ha of polders that will be converted into salt and brackish tidal marsh.

- Along the river Grensmaas more than 400ha of flower-rich floodplain grasslands and natural gravel bed river dynamics were restored on former intensively used agricultural land after removal or lowering of the artificial embankments (Van Looy 2008).

- $\quad$ Along the river IJzer old plans for higher embankments to protect natural floodplain areas from flooding were cancelled at the turn of the century after decades of hard debate and 1000ha of floodplain ecosystems are now being restored to their full ecological potential (e.g. (De Rycke et al. 2004)).

The future perspectives for a more natural floodplain functioning of the large river valleys in Flanders is generally rather good, but not in all cases there is a large benefit for biodiversity. Floodplain grasslands are often still in intensive agricultural use or low-productive semi-natural grasslands suffer from deposition of eutrophic sediments as is the case along the river Dijle (De Becker \& De Bie 2013). The smaller river valleys more upstream are often managed by the provincial authorities and there is 
a mixed picture here. On one hand we see continued pressure from agriculture to have the water levels as favorable as possible for agricultural exploitation, resulting in for instance an intensive river and ditch management. On the other hand small scaled flood control areas have been constructed in many places, recognizing the need for stocking excess water during peak discharges. Unfortunately their design is often not very beneficial for biodiversity: they are generally constructed in the lowest places where permanent grassland persisted and many flood control areas function 'off line', meaning they are kept dry as long as possible for agriculture, excluding any possibility for natural riparian dynamics and spontaneous succession. Allowing natural buffer zones along the smaller rivers are still not a wide spread practice in Flanders. According to our calculations the area of valuable floodplain grasslands and forests can be increased with 78,000 ha, with 15,000 ha already protected for nature by spatial planning or Natura 2000 designation.

Restoration projects of nutrient poor wet grasslands and heaths on temporary or permanently wet soils are much rarer and more small scaled. Societal benefits such as flood protection are of no importance here. Hence they are mainly restricted to nature reserves where young forest encroachment is removed, often in combination with removal of the rich top layer of the soil to activate the seed bank. There are also examples of successful restoration starting from former intensively used agricultural grasslands. Fine-tuning of the local hydrological conditions is in all cases crucial. Fen meadows are mainly restored where modern agriculture has left the area. After the traditional mowing practice without fertilization is reinstalled biodiversity values can recover. New reed marshes are mostly found in the margins of newly created water bodies and on artificially raised land with heavy soils and poor drainage. Sedge marshes are most of the times a result of spontaneous succession of abandoned fen meadows. In all cases cessation of management will on the long term lead to a forested version of the habitat. The area suitable for restoration of all these wetland types combined is estimated at 59,000 ha of which 29,000 ha is already protected for nature by spatial planning or Natura 2000 designation. We conclude that for a large proportion of suitable sites for wetland restoration the legal protection status is already in place to get started. In this perspective, the rather low ambition level for expansion of Natura 2000 wetland habitat types and habitats for Natura 2000 wetland species is striking, particularly those of open landscapes.

\section{References}

Beauchard, O., S. Jacobs, T.J.S. Cox, T. Maris, D. Vrebos, A. Van Braeckel, and P. Meire. 2011. A new technique for tidal habitat restoration: Evaluation of its hydrological potentials. Ecological Engineering 37: 1849-1858. http://dx.doi.org/10.1016/j.ecoleng.2011.06.010. 
De Becker, P. and E. De Bie. 2013. Verzamelen van basiskennis en ontwikkeling van een beoordelingsof afwegingskader voor de ecologische effectanalyse van overstromingen. Instituut voor Natuur- en Bosonderzoek.

De Rycke, A., K. Devos, M. Sas, and K. Decleer. 2004. A protection strategy for the floodplains of the River "Yzer"(Flanders, Belgium). Journal of Water and Land Development 8: 35-48.

https://www.infona.pl/resource/bwmeta1.element.baztech-article-BAT9-0021-0004/tab/summary. Jacobs, S., O. Beauchard, E. Struyf, T. Cox, T. Maris, and P. Meire. 2009. Restoration of tidal freshwater vegetation using controlled reduced tide (CRT) along the Schelde Estuary (Belgium). Estuar. Coast. Shelf Sci. 85: 368-376. http://10.1016/i.ecss.2009.09.004.

Temmerman, S., P. Meire, T.J. Bouma, P.M.J. Herman, T. Ysebaert, and H.J. De Vriend. 2013. Ecosystem-based coastal defence in the face of global change. Nature 504: 79-83.

$10.1038 /$ nature12859.

Van Looy, K. 2008. 36. Vallei van de Grensmaas. 135-137 135-137. In Decleer, K., editors. Ecological Restoration in Flanders (Belgium). Vol. INBO.M.2008.04, Research Institute for Nature and Forest, Brussels. 


\section{Appendix 9. References to individual chapters (in Dutch) of the Flanders regional ecosystem service, as listed in Table 2.}

Cools N., Van Gossum P. (2014). Hoofdstuk 18 - Ecosysteemdienst behoud van de bodemvruchtbaarheid. (INBO.R.2014.1988205). In Stevens, M. et al. (eds.), Natuurrapport - Toestand en trend van ecosystemen en ecosysteemdiensten in Vlaanderen. Technisch rapport. Mededelingen van het Instituut voor Natuur-en Bosonderzoek, INBO.M.2014.1988582, Brussel. http://www.nara.be/behoud-van-de-bodemvruchtbaarheid

De Blust G., Van Renterghem T.(2014). Hoofdstuk 20- Ecosysteemdienst regulatie van geluidsoverlast. (INBO.R.2014.2008296). In Stevens, M. et al. (eds.), Natuurrapport - Toestand en trend van ecosystemen en ecosysteemdiensten in Vlaanderen. Technisch rapport. Mededelingen van het Instituut voor Natuur-en Bosonderzoek, INBO.M.2014.1988582, Brussel. http://www.nara.be/regulatie-van-geluidsoverlast

De Bruyn L. (2014). Hoofdstuk 16 - Ecosysteemdienst bestuiving. (INBO.R.2014.1994351). In Stevens, M. et al. (eds.), Natuurrapport - Toestand en trend van ecosystemen en ecosysteemdiensten in Vlaanderen. Technisch rapport. Mededelingen van het Instituut voor Natuur- en Bosonderzoek, INBO.M. 2014.1988582, Brussel. http://www.nara.be/bestuiving

De Bruyn, L. (2014). Hoofdstuk 17 - Ecosysteemdienst plaagbeheersing. (INBO.R.2014.1994543). In Stevens, M. et al. (eds.), Natuurrapport - Toestand en trend van ecosystemen en ecosysteemdiensten in Vlaanderen. Technisch rapport. Mededelingen van het Instituut voor Natuur- en Bosonderzoek, INBO.M. 2014.1988582, Brussel. http://www.nara.be/plaagbeheersing

Lettens S., Demolder H., Van Daele T. (2014). Hoofdstuk 24 - Ecosysteemdienst regulatie van het globaal klimaat. (INBO.R.2014.1993545). In Stevens, M. et al. (eds.), Natuurrapport - Toestand en trend van ecosystemen en ecosysteemdiensten in Vlaanderen. Technisch rapport. Mededelingen van het Instituut voor Natuur-en Bosonderzoek, INBO.M.2014.1988582, Brussel. http://www.nara.be/regulatie-van-het-globaalklimaat

Neirynck J., Stevens M. (2014). Hoofdstuk 19- Ecosysteemdienst regulatie van luchtkwaliteit. (INBO.R.2014.1986607). In Stevens, M. et al. (eds.), Natuurrapport - Toestand en trend van ecosystemen en ecosysteemdiensten in Vlaanderen. Technisch rapport. Mededelingen van het Instituut voor Natuur-en Bosonderzoek, INBO.M.2014.1988582, Brussel. http://www.nara.be/regulatie-van-luchtkwaliteit

Provoost, S., Dan, S., Jacobs, S. (2014). Hoofdstuk 23 - Ecosysteemdienst kustbescherming (INBO.R.2014.1988082). In Stevens, M. et al. (eds.), Natuurrapport - Toestand en trend van ecosystemen en ecosysteemdiensten in Vlaanderen. Technisch rapport. Mededelingen van het Instituut voor Natuur-en Bosonderzoek, INBO.M.2014. 1988582, Brussel. http://www.nara.be/kustbescherming

Scheppers T., Casaer J. (2014). Hoofdstuk 12 - Ecosysteemdienst wildbraadproductie. (INBO.R.2014.1988003). In Stevens, M. et al. (eds.), Natuurrapport - Toestand en trend van ecosystemen en ecosysteemdiensten in Vlaanderen. Technisch rapport. Mededelingen van het Instituut voor Natuur- en Bosonderzoek, INBO.M.2014.1988582, Brussel. http://www.nara.be/wildbraadproductie

Schneiders A., Spanhove T., Breine J., Zomlot Z., Verbeiren B., Batelaan O., Decleyre D. (2014). Hoofdstuk 22 Ecosysteemdienst regulering overstromingsrisico. (INBO.R.2014.2001135). In Stevens, M. et al. (eds.), Natuurrapport - Toestand en trend van ecosystemen en ecosysteemdiensten in Vlaanderen. Technisch rapport. Mededelingen van het Instituut voor Natuur- en Bosonderzoek, INBO.M.2014.1988582, Brussel. http://www.nara.be/regulatie-van-overstromingsrisico

Simoens I., Thoonen M., Meiresonne L., Van Daele T. (2014). Hoofdstuk 26 - Ecosysteemdienst groene ruimte voor buitenactiviteiten. (INBO.R.2014.1987887). In Stevens, M. et al. (eds.), Natuurrapport - Toestand en trend van ecosystemen en ecosysteemdiensten in Vlaanderen. Technisch rapport. Mededelingen van het Instituut voor Natuur- en Bosonderzoek, INBO.M.2014.1988582, Brussel. http://www.nara.be/groene-ruimte-voor$\underline{\text { buitenactiviteiten }}$ 
Vandekerkhove K., De Keersmaeker L., Demolder H., Esprit M., Thomaes A., Van Daele T., Van der Aa B. (2014). Hoofdstuk 13- Ecosysteemdienst houtproductie. (INBO.R.2014. 1993289). In Stevens, M. et al. (eds.), Natuurrapport - Toestand en trend van ecosystemen en ecosysteemdiensten in Vlaanderen. Technisch rapport. Mededelingen van het Instituut voor Natuur- en Bosonderzoek, INBO.M.2014. 1988582, Brussel.

http://www.nara.be/houtproductie

Van Der Biest K., Van Gossum P., Struyf E., Van Daele T. (2014). Hoofdstuk 21 - Ecosysteemdienst regulatie van erosierisico (INBO.R.2014.2065899). In Stevens, M. et al. (eds.), Natuurrapport - Toestand en trend van ecosystemen en ecosysteemdiensten in Vlaanderen. Technisch rapport. Mededelingen van het Instituut voor Natuur-en Bosonderzoek, INBO.M.2014.1988582, Brussel. http://www.nara.be/regulatie-van-erosierisico

Van Gossum P., Danckaert, S., Spanhove, T., Wils, C. (2014). Hoofdstuk 11 - Ecosysteemdienst voedselproductie. (INBO.R.2014.1987588). In Stevens, M. et al. (eds.), Natuurrapport - Toestand en trend van ecosystemen en ecosysteemdiensten in Vlaanderen. Technisch rapport. Mededelingen van het Instituut voor Natuur- en Bosonderzoek, INBO.M.2014.1988582, Brussel. http://www.nara.be/voedselproductie

Van Kerckvoorde A., Van Reeth W. (2014). Hoofdstuk 14 - Ecosysteemdienst productie van energiegewassen. (INBO.R.2014.1987641). In Stevens, M. et al. (eds.), Natuurrapport - Toestand en trend van ecosystemen en ecosysteemdiensten in Vlaanderen. Technisch rapport. Mededelingen van het Instituut voor Natuur-en Bosonderzoek, INBO.M.2014.1988582, Brussel. http://www.nara.be/productie-van-energiegewassen

Vrebos, D., Staes, J., Jacobs, S. en Meire, P. (2014). Hoofdstuk 15 - Ecosysteemdienst waterproductie. (INBO.R.2014.1994463). In Stevens, M. et al. (eds.), Natuurrapport - Toestand en trend van ecosystemen en ecosysteemdiensten in Vlaanderen. Technisch rapport. Mededelingen van het Instituut voor Natuur-en Bosonderzoek, INBO.M. 2014.1988582, Brussel. http://www.nara.be/waterproductie

Vrebos, D., Staes, J., Jacobs, S., Van Looy, K. en Meire, P. (2014). Hoofdstuk 25 - Ecosysteemdienst regulatie van waterkwaliteit. (INBO.R. 2014.2001010). In Stevens, M. et al. (eds.), Natuurrapport - Toestand en trend van ecosystemen en ecosysteemdiensten in Vlaanderen. Technisch rapport. Mededelingen van het Instituut voor Natuur-en Bosonderzoek, INBO.M. 2014.1988582, Brussel. http://www.nara.be/regulatie-van-waterkwaliteit 